\title{
Targeted Therapy With Immunoconjugates for Multiple Myeloma
}

\author{
Wassilis S. C. Bruins, Sonja Zweegman, Tuna Mutis and Niels W. C. J. van de Donk*
}

Department of Hematology, Cancer Center Amsterdam, Amsterdam UMC, Vrije Universiteit Amsterdam, Amsterdam, Netherlands

The introduction of proteasome inhibitors $(\mathrm{Pl})$ and immunomodulatory drugs (IMiD) has markedly increased the survival of multiple myeloma (MM) patients. Also, the unconjugated monoclonal antibodies (mAb) daratumumab (anti-CD38) and elotuzumab (anti-SLAMF7) have revolutionized MM treatment given their clinical efficacy and safety, illustrating the potential of targeted immunotherapy as a powerful treatment strategy for MM. Nonetheless, most patients eventually develop PI-, IMiD-, and mAb-refractory disease because of the selection of resistant MM clones, which associates with a poor prognosis. Accordingly, these patients remain in urgent need of new therapies

OPEN ACCESS

Edited by:

Nicola Giuliani,

University of Parma, Italy

Reviewed by:

Loredana Ruggeri,

University of Perugia, Italy

Aristeidis Chaidos,

Imperial College London,

United Kingdom

*Correspondence:

Niels W. C. J. van de Donk n.vandedonk@amsterdamumc.nl

Specialty section:

This article was submitted to Cancer Immunity and Immunotherapy,

a section of the journal

Frontiers in Immunology

Received: 30 January 2020

Accepted: 11 May 2020

Published: 19 June 2020

Citation:

Bruins WSC, Zweegman S, Mutis T and van de Donk NWCJ (2020)

Targeted Therapy With Immunoconjugates for Multiple

Myeloma. Front. Immunol. 11:1155.

doi: 10.3389/fimmu.2020.01155 with novel mechanisms of action. In this respect, mAbs or mAb fragments can also be utilized as carriers of potent effector moieties to specifically target surface antigens on cells of interest. Such immunoconjugates have the potential to exert anti-MM activity in heavily pretreated patients due to their distinct and pleiotropic mechanisms of action. In addition, the fusion of highly cytotoxic compounds to mAbs decreases the off-target toxicity, thereby improving the therapeutic window. According to the effector moiety, immunoconjugates are classified into antibody-drug conjugates, immunotoxins, immunocytokines, or radioimmunoconjugates. This review will focus on the mechanisms of action, safety and efficacy of several promising immunoconjugates that are under investigation in preclinical and/or clinical MM studies. We will also include a discussion on combination therapy with immunoconjugates, resistance mechanisms, and future developments.

Keywords: multiple myeloma, immunoconjugates, antibody-drug conjugates, immunotoxins, immunocytokines, radioimmunoconjugates, monoclonal antibodies, immunotherapy

\section{INTRODUCTION}

Multiple myeloma (MM) is a malignancy of plasma cells, which typically proliferate within the bone marrow. $\mathrm{MM}$ is the second most prevalent hematologic malignancy (1), accounting for 159985 incident cases and 106105 mortality cases globally in 2018 (2). Over the past decades, the prognosis of MM patients has markedly improved due to the introduction of high-dose melphalan therapy with autologous stem cell transplantation (ASCT), proteasome inhibitors (PI), and immunomodulatory drugs (IMiD). However, the majority of patients eventually become refractory to all available therapies because of the selection of drug-resistant MM clones during treatment (3-5). Also, the outcome remains especially poor for patients with an unfavorable 
cytogenetic profile (6). Accordingly, further improvements in treatment outcome will require the development of new anti-MM therapies with novel mechanisms of action.

Recently, advances in MM research have led to the emergence of promising treatment approaches such as cellularand monoclonal antibody ( $\mathrm{mAb}$ )-based immunotherapies. In this respect, the unconjugated mAbs daratumumab (antiCD38) and elotuzumab (anti-SLAMF7) have shown impressive anti-MM activity and a beneficial toxicity profile. Although these antibodies have transformed the treatment of both heavily pretreated and newly diagnosed MM, most patients eventually develop resistance to mAbs during the treatment course, which is associated with poor survival (7). Prolonged remission of these patients may eventually be realized by exploring the ways in which these mAb-based therapies can be enhanced.

A highly appealing strategy to exploit the targeting power of antibodies or antibody fragments is to utilize them as carriers of potent effector moieties to the tumor cells. Such immunoconjugates aim to specifically expose target cells to high amounts of cytotoxic or immune-modulating molecules, compared with non-target cells, resulting in an improved therapeutic window. Depending on the effector moiety used, immunoconjugates are classified into four subgroups: antibodydrug conjugates (ADC), immunotoxins, immunocytokines, and radioimmunoconjugates (Figure 1).

In this review, we will focus on the most promising immunoconjugates for the treatment of $\mathrm{MM}$, in different phases of preclinical and clinical development. We will provide an overview of the different classes of immunoconjugates, with a strong focus on mechanisms of action, efficacy, and safety profile. In addition, we will discuss combination strategies with immunoconjugates, off-target toxicities, resistance mechanisms, and future developments.

\section{ANTIBODY-DRUG CONJUGATES}

ADCs are a rapidly growing class of immunotherapeutic drugs used for the treatment of solid and hematologic malignancies (8-11). An ADC consists of a mAb or mAb fragment which is armed with a cytotoxic drug (also known as the payload, warhead or small-molecule) via a cleavable or non-cleavable linker. When the antibody component binds to its specific cell surface antigen, the antigen-ADC complex is internalized into the cell and the payload is released into the cytoplasm via linker cleavage or linker and/or antibody degradation in the endolysosomes. The payload then interferes with vital cellular functions, resulting in cell death (Figure 2). Thus, ADCs are "guided missiles" that combine the lethal properties of cytotoxic payloads with the selectivity of mAbs. Additionally, some ADCs induce Fc-mediated effector functions including antibody-dependent cellular cytotoxicity (ADCC) and antibody-dependent cellular phagocytosis (ADCP) $(12,13)$.

The design of ADCs is generally more complex as opposed to unconjugated $\mathrm{mAbs}$ - the performance of each ADC component is important for specific anti-tumor activity and safety. Preferably, the antibody targets a tumor-associated antigen displaying a high density on cancer cells as opposed to normal cells, whereas linker stability is critical when the $\mathrm{ADC}$ is en route toward its target in the bloodstream to avoid ADC disintegration. Suitable payloads are highly cytotoxic at low concentrations, easily conjugatable to antibodies, and stable when administered in vivo. Commonly used payloads include anti-mitotic microtubule blockers such as maytansinoid and auristatin, DNA-damaging agents such as pyrrolobenzodiazepine and calicheamicin, and the RNA polymerase inhibitor amanitin (14).

Although the basic idea behind ADCs was already introduced back in the 1960s (15), their success in oncology has

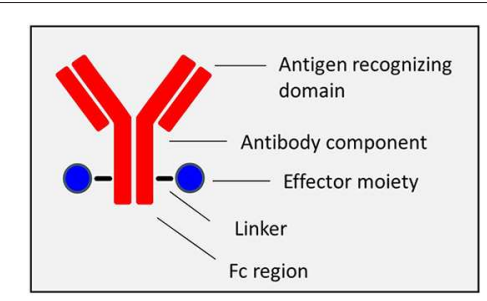

Antibody-drug conjugate

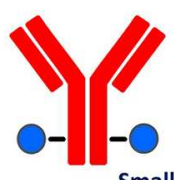

Small-molecule drug

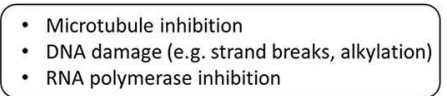

- Microtubule inhibition

- RNA polymerase inhibition
Immunotoxin

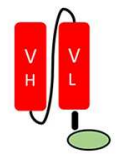

Protein toxin

- Ribosome inactivation

- Pore formation in cell membrane
Immunocytokine

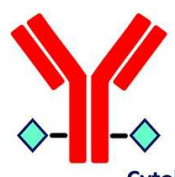

Cytokine

- Cell cycle arrest/apoptosis

- Immunomodulatory effects

- Anti-angiogenesis

- Increased tumor cell immunogenicity
Radioimmunoconjugate

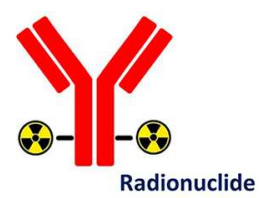

- DNA strand breaks

FIGURE 1 | The different subgroups of immunoconjugates with the main functions of their effector moieties. 


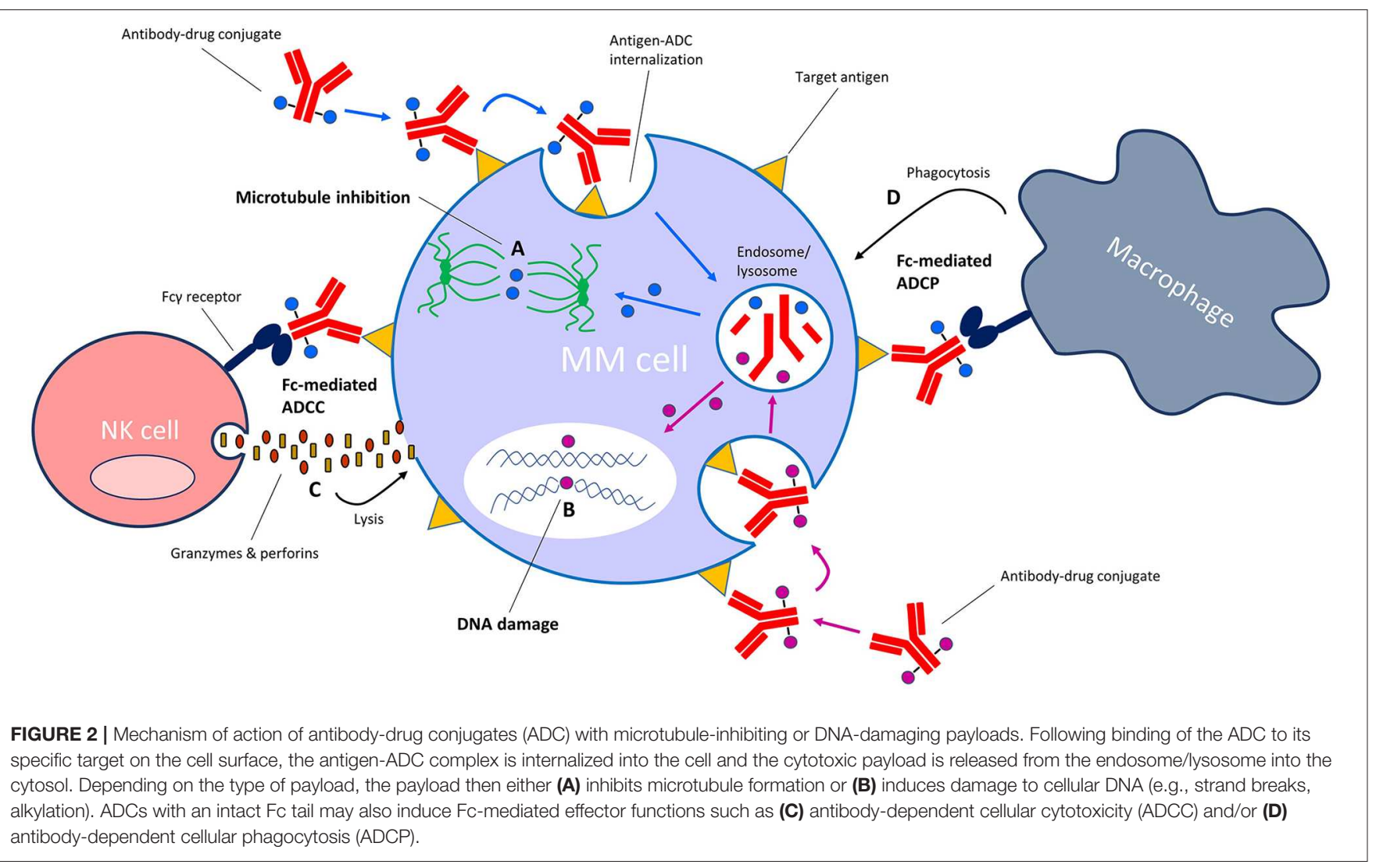

especially accelerated in recent years. To date, four ADCs have been granted (conditional) marketing authorization by the Food and Drug Administration (FDA) and European Medicines Agency (EMA) for the treatment of hematologic malignancies: gemtuzumab-ozogamicin (anti-CD33; Mylotarg) for acute myeloid leukemia, brentuximab vedotin (anti-CD30; Adcetris) for Hodgkin lymphoma, inotuzumab ozogamicin (antiCD22; Besponsa) for acute lymphoid leukemia, and polatuzumab vedotin (anti-CD79b; Polivy) for diffuse large B-cell lymphoma. For MM, several ADCs have reached the clinical phase of drug testing, while others are still in preclinical stages (Table 1). In the next section, we will discuss several of these ADCs with a focus on ADCs that are most advanced in clinical evaluation, or ADCs that have shown notable preclinical efficacy.

\section{ADCs Targeting B Cell Maturation Antigen Belantamab Mafodotin (GSK2857916)}

Belantamab mafodotin consists of a humanized, afucosylated B cell maturation antigen (BCMA)-specific IgG1 mAb fused to the payload monomethyl auristatin $\mathrm{F}$ (MMAF) by a non-cleavable linker $(13,16-20)$. BCMA is a member of the tumor necrosis factor receptor superfamily that is exclusively expressed on latestage B cells and plasma cells, as well as on MM cells $(16,60,61)$. BCMA promotes the survival of long-lived plasma cells and MM cells following interaction with its ligands A Proliferation Inducing Ligand (APRIL) and B-cell Activating Factor (BAFF) (60-63). Because BCMA expression is restricted to (malignant) plasma cells and a subset of mature B cells, it is an attractive target for anti-MM immunotherapy (64-66).

Belantamab mafodotin showed potent and pleiotropic anti$\mathrm{MM}$ activity in preclinical in vitro and in vivo models, without significant off-target cytotoxicity on BCMA-negative immune effector cells or bone marrow stromal cells (BMSC) $(13,16)$. The MMAF payload induces anti-proliferative (cell cycle arrest in $\mathrm{G} 2 / \mathrm{M}$ phase) and pro-apoptotic anti-MM effects. In addition, belantamab mafodotin triggers Fc-receptor mediated effector functions including NK cell-mediated ADCC and macrophagemediated ADCP via its afucosylated Fc tail. Furthermore, belantamab mafodotin induces immunogenic cell death (21), and also inhibits NF-kB signaling by competing with APRIL and BAFF for binding to BCMA (13).

Based on these preclinical findings, the ADC was evaluated in a first-in-human, phase 1 dose-escalation/expansion study (DREAMM-1) $(17,18)$. Thirty-eight patients were enrolled in the dose-escalation phase. The MTD was not identified, but based on clinical safety and efficacy data, the recommended dose for the expansion phase was defined as $3.4 \mathrm{mg} / \mathrm{kg}$ administered every three weeks (17). In the expansion phase, 35 additional patients were included (>4 lines: 57\%; PI-refractory: 97\%; IMiDrefractory: 94\%; daratumumab-refractory: 40\%) (18). The most reported adverse events included corneal events (69\% of patients, mostly grade $1 / 2$ [54\%]), thrombocytopenia (grade $3 / 4$ in $34 \%$ of patients), and anemia (grade 3 in $17 \%$ of patients). In the expansion phase, at least partial response (PR) was observed in 
TABLE 1 | List of antibody-drug conjugates investigated for multiple myeloma.

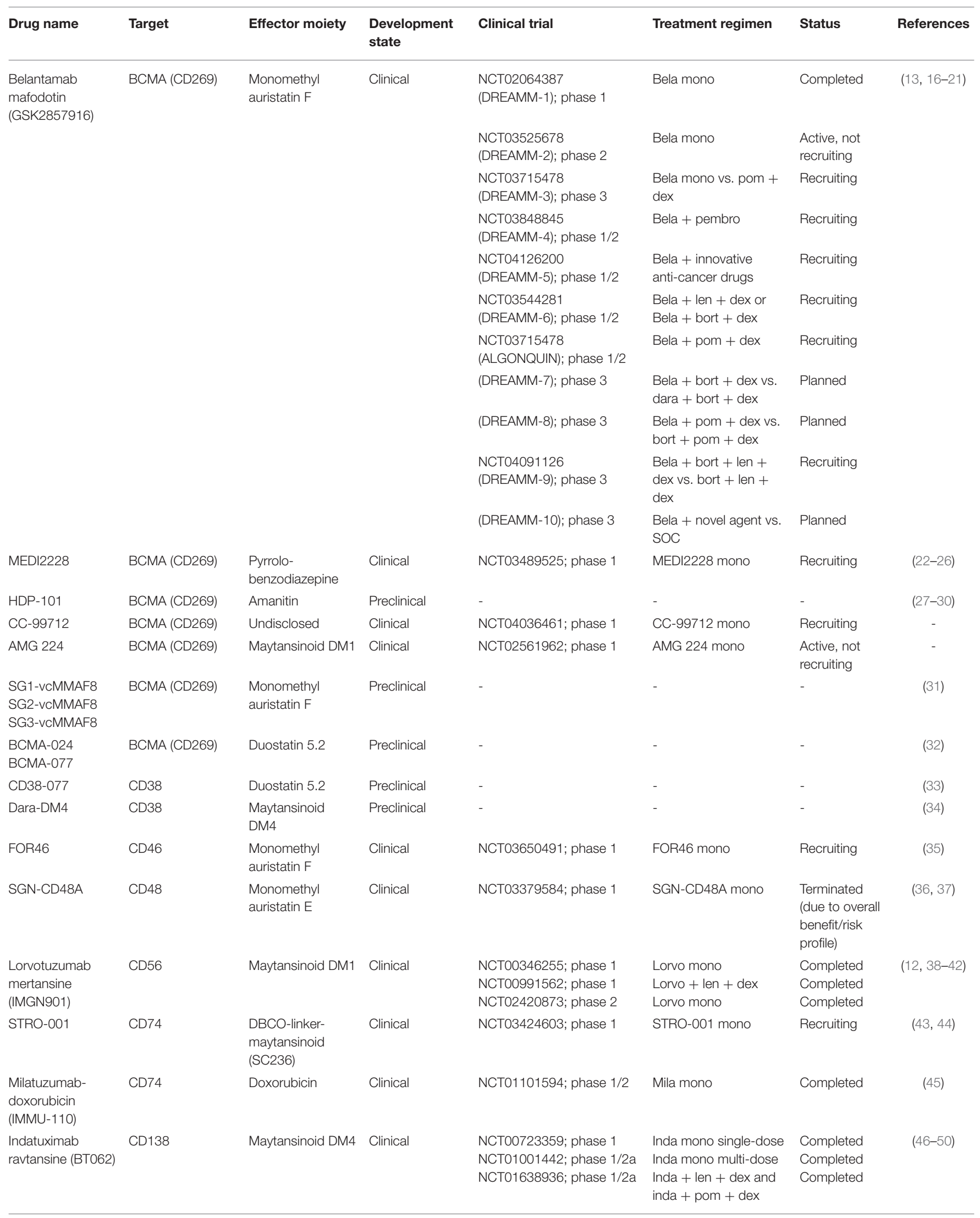


TABLE 1 | Continued

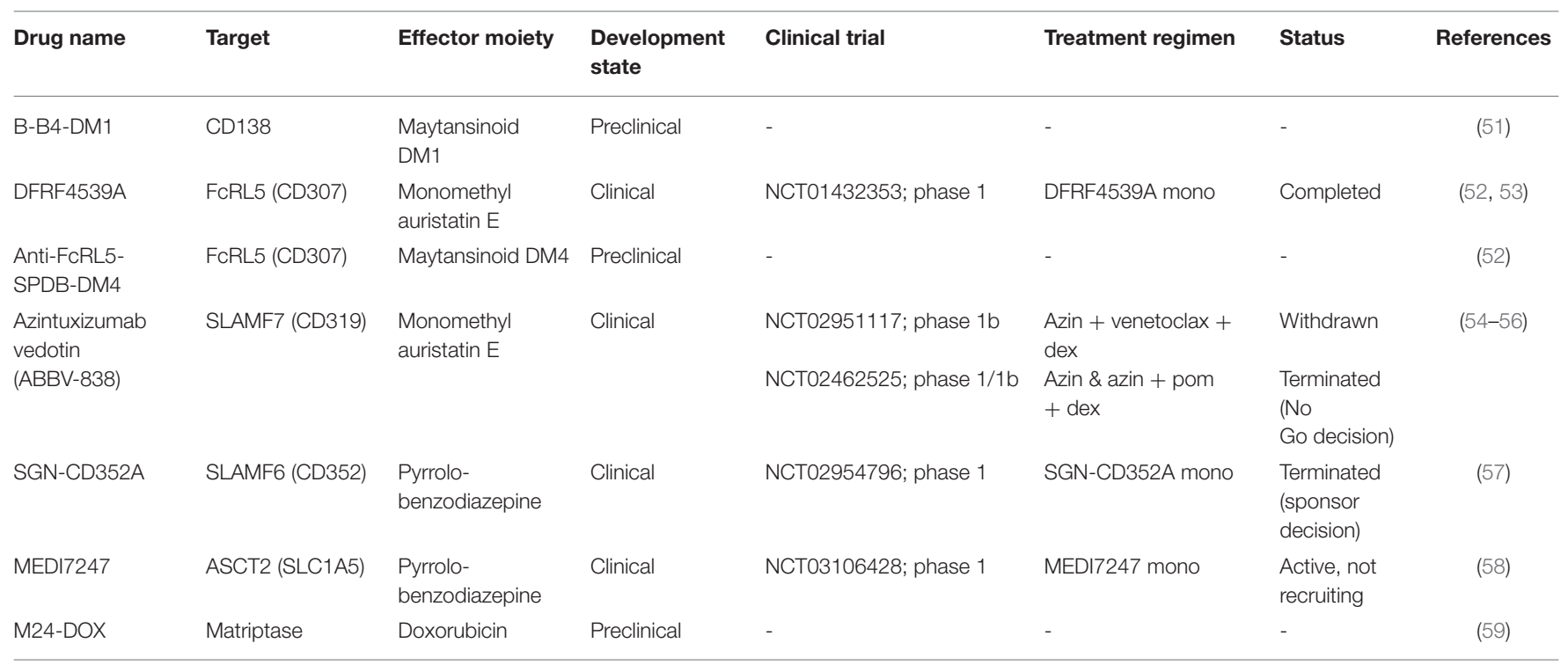

azin, azintuxizumab vedotin; bela, belantamab mafodotin; bort, bortezomib; dara, daratumumab; dex, dexamethasone; inda, indatuximab ravtansine; len, lenalidomide; lorvo, lorvotuzumab mertansine; mila, milatuzumab-doxorubicin; mono, monotherapy; pembro, pembrolizumab; pom, pomalidomide; SOC, standard-of-care; vs, versus.

$60 \%$ of patients, with $54 \%$ achieving a very good partial response (VGPR) or better. Median progression-free survival (PFS) was 12.0 months, with a median duration of response of 14.3 months.

The DREAMM-2 study was initiated to further assess the efficacy and safety of two doses of single-agent belantamab mafodotin (2.5 or $3.4 \mathrm{mg} / \mathrm{kg}$ administered every 3 weeks) in patients with $\geq$ three prior lines of treatment including disease refractory to an IMiD or PI, and disease refractory or intolerant to a CD38-targeting antibody (19). This two-arm phase 2 study enrolled 196 relapsed/refractory MM patients (>4 lines: $83 \%$; bortezomib-refractory: $76 \%$; carfilzomib-refractory: $61 \%$; lenalidomide-refractory: $89 \%$; pomalidomide-refractory: $82 \%$; daratumumab-refractory: $96 \%$ ). The overall response rate (ORR) was $31 \%$ in the $2.5 \mathrm{mg} / \mathrm{kg}$ cohort and $34 \%$ in the $3.4 \mathrm{mg} / \mathrm{kg}$ cohort, with at least VGPR in 19 and $20 \%$ of patients treated with 2.5 and $3.4 \mathrm{mg} / \mathrm{kg}$, respectively. The median PFS was 2.9 months in the $2.5 \mathrm{mg} / \mathrm{kg}$ cohort and 4.9 months in the 3.4 $\mathrm{mg} / \mathrm{kg}$ cohort. At the time of analysis, overall survival (OS) data were immature. Toxicity was similar to what was observed in the previous DREAMM-1 study with keratopathy, anemia, and thrombocytopenia as the most reported side effects. Keratopathy (changes to corneal epithelium) was the most common reason for treatment discontinuation, dose reduction, or dose delay. Keratopathy could be effectively managed with dose reductions and delays, and the use of artificial tears. Prophylactic use of corticosteroid eye drops seems to be ineffective. The mechanism of corneal damage is probably related to non-specific uptake of the MMAF payload by actively dividing corneal epithelial cells via macropinocytosis (67). Notably, corneal events were also observed in other clinical trials with other ADCs containing MMAF (68). Infusion-related reactions occurred in $19 \%$ of patients (predominantly during the first infusion) and were mostly grade $1 / 2$. The $2.5 \mathrm{mg} / \mathrm{kg}$ dose was associated with a more favorable toxicity profile and comparable anti-MM activity when compared to the $3.4 \mathrm{mg} / \mathrm{kg}$ dose, and therefore selected as the recommended dose for future studies. The FDA has currently granted a priority review of belantamab mafodotin for the treatment of relapsed/refractory MM patients who have previously received an IMiD, PI and anti-CD38 mAb, whereas the EMA has granted PRIME designation to the ADC.

In preclinical models, preincubation of effector peripheral blood mononuclear cells (PBMC) with the IMiD lenalidomide enhanced belantamab mafodotin-mediated ADCC against MM cell lines or primary MM cells (13). Also, cotreatment of MM cells with both agents in absence of PBMCs enhanced the direct cytotoxicity of the ADC. Furthermore, in vitro anti-MM activity was augmented by combining belantamab mafodotin with a gamma-secretase inhibitor, which inhibits BCMA shedding from the cell surface, thereby increasing surface BCMA density and decreasing soluble BCMA levels (20). These preclinical studies provide the rationale for the evaluation of belantamab mafodotin in combination with other agents in planned or already ongoing clinical studies (Table 1).

\section{MEDI2228}

MEDI2228 is a novel ADC comprised of a fully human BCMA-binding Ab1 antibody conjugated to DNA-damaging agent pyrrolobenzodiazepine via a protease-cleavable linker (22-26). In preclinical models, MEDI2228 effectively killed the majority of MM cell lines and primary MM cells from relapsed/refractory patients, also in the presence of BMSCs or high levels of soluble BCMA. Activity was independent of surface BCMA levels on MM cells, and unaffected by the stimulation of MM cells with IL-6. BCMA-negative cells were not killed. In vivo, a single injection of MEDI2228 eliminated tumors in MM mouse models. Importantly, MEDI2228 and bortezomib synergistically decreased viability of drug-sensitive and drug-resistant MM cells in vitro, and in vivo cotreatment 
with both agents in mice augmented the eradication of MM tumors and improved survival. In contrast to an MMAF analog, the PBD payload induced DNA damage responses (DDR) and synergized with multiple DDR-inhibitors $(23,25)$. A phase 1 dose-escalation/-expansion study of MEDI2228 as monotherapy in relapsed/refractory patients is currently ongoing (NCT03489525).

\section{HDP-101}

HDP-101 consists of a BCMA-specific antibody fused to the RNA polymerase inhibitor amanitin. (27-30). HDP-101 induced dosedependent lysis of MM cell lines and primary MM cells, even when BCMA expression was low. Notably, the ability of HDP101 to kill primary MM cells was higher compared with the activity of the same anti-BCMA mAb conjugated to MMAF. BCMA-negative cell lines and patient BMSCs were spared from cytotoxicity. Interestingly, HDP-101 was especially potent in preclinical models with a knockout of tumor suppressor TP53 and knockdown of RNA polymerase POLR2A, which mimics the deletion of $17 \mathrm{p}$ in a subtype of high-risk MM patients (29). HDP-101 also had anti-MM activity in mouse models. In a doseescalation study in cynomolgus monkeys, a drug serum halflife of around 12 days was reached. HDP-101 was well-tolerated with only moderate and transient increases in liver enzymes and lactate dehydrogenase. A first-in-human clinical trial application is expected to be submitted in the second half of 2020 (69).

\section{Other BCMA-Targeting ADCs}

Table 1 provides an overview of the other BCMA-targeting ADCs AMG-224, CC-99712, and SG1-auristatin.

\section{ADCs Targeting Other Markers} Indatuximab Ravtansine (BT062)

This ADC is comprised of the microtubule-blocker maytansinoid DM4 linked by cleavable disulfide linkers to a chimeric antiCD138 (syndecan-1) IgG4 antibody (46-50). CD138 is a transmembrane heparan sulfate proteoglycan involved in cell proliferation, cell migration, cell-cell-and cell-matrix adhesion (70, 71). Within the human hematopoietic system, CD138 is considered a specific marker for normal and malignant plasma cells $(72,73)$. However, CD138 is also expressed on epithelialand endothelial cells, as well as on fibroblasts and hepatocytes $(70,71,74)$.

Indatuximab ravtansine induced dose-dependent cytotoxicity against CD138-positive MM cell lines and primary MM cells, while sparing CD138-negative PBMCs from healthy donors (46). Treatment of MM cell lines revealed G2-M cell cycle arrest with subsequent caspase-dependent apoptosis as a mechanism of action. Cytotoxicity could not be inhibited by addition of exogenous IL-6 or insulin-like growth factor-1, or coculture with BMSCs. Interestingly, indatuximab ravtansine inhibited adhesion of MM cells to BMSCs. Indatuximab ravtansine also inhibited tumor growth and improved survival in MM mouse models.

Altogether, this supported initiation of a phase 1 study (50). Indatuximab ravtansine as a single agent was initially administered once every 3 weeks in 31 relapsed/refractory MM patients (median of prior lines: 7; 100\% received prior treatment with bortezomib, $100 \%$ lenalidomide or thalidomide, $61 \%$ ASCT). The maximum tolerated dose (MTD) was defined as $160 \mathrm{mg} / \mathrm{m}^{2}$ with two patients developing dose-limiting toxicities (DLT) at the dose of $200 \mathrm{mg} / \mathrm{m}^{2}$ including mucosal inflammation and palmar-plantar erythrodysesthesia syndrome. In this study, the safety profile of indatuximab ravtansine was generally acceptable but the ORR was low (3.2\%), and therefore another administration schedule was explored in a phase $1 / 2 \mathrm{a}$ study (50). In this multi-dosing schedule, indatuximab ravtansine was administered on days 1, 8 and 15 of a four-week cycle to 34 relapsed/refractory MM patients (median of prior lines: 5; 100\% received prior treatment with bortezomib, 100\% lenalidomide or thalidomide, $65 \%$ ASCT). Two out of four patients experienced DLTs at $160 \mathrm{mg} / \mathrm{m}^{2}$ (one neutropenia, and one transaminitis), and therefore the MTD was established as $140 \mathrm{mg} / \mathrm{m}^{2}$. The safety profile was acceptable, with the most frequently reported adverse events being diarrhea (37\%), fatigue (34\%), anemia (31\%), and nausea $(23 \%)$ ( $88 \%$ of adverse events grade $1 / 2)$. At least PR was achieved in $5.9 \%$ of patients, minor response (MR) in $8.8 \%$, and stable disease (SD) in $61.8 \%$. Median PFS and median OS were 3.0 and 26.7 months, respectively.

Based on preclinical data showing synergy between indatuximab ravtansine and lenalidomide $(47,49)$, a second phase 1/2a study (NCT01638936) was initiated in which the ADC (administered on day 1, 8, and 15) was combined with low-dose dexamethasone and either lenalidomide or pomalidomide in a four-week cycle (48). Forty-seven patients with 1-6 prior therapies were treated in combination with lenalidomide/dexamethasone (three patients at $80 \mathrm{mg} / \mathrm{m}^{2}, 38$ at $100 \mathrm{mg} / \mathrm{m}^{2}, 6$ at $120 \mathrm{mg} / \mathrm{m}^{2}$ ). The recommended phase 2 dose (RP2D) of indatuximab ravtansine in this cohort was identified as $100 \mathrm{mg} / \mathrm{m}^{2}$. Again, most frequent toxicities were diarrhea, fatigue, and nausea (approximately 90\% were grade $1 / 2$ ). Of the 43 patients evaluable for response, 33 patients $(77 \%)$ achieved a PR or better with a median response duration of 21.0 months. In the 13 patients who were previously exposed to both lenalidomide and bortezomib, at least PR was achieved in 54\%. For the whole group of patients, the median PFS of indatuximab ravtansine combined with lenalidomide/dexamethasone was 16.4 months. An additional 17 patients, with at least two prior therapies including both lenalidomide and bortezomib, were treated with indatuximab ravtansine at the RP2D in combination with pomalidomide/dexamethasone. Of the 14 patients evaluable for response, $79 \%$ achieved a $\mathrm{PR}$ or better. The median PFS had not yet been reached after a median follow-up of 7.5 months. However, to the best of our knowledge, the clinical development of this drug has been halted, which may be related to its minimal single agent activity. The limited activity as monotherapy may be explained by the mechanism of action of the maytansinoid payload, which affects only proliferating cells. In addition, several studies show that CD138 can be rapidly shed from the cell surface (75), whereby high levels of soluble CD138 may act as a drug sink. 


\section{Lorvotuzumab Mertansine (IMGN901)}

This ADC consists of the cytotoxic maytansinoid DM1 payload (microtubule inhibitor) attached to the humanized anti-CD56 IgG1 antibody N901 via a disulfide linker (38-42). CD56, originally described as neuronal cell adhesion molecule (NCAM) (76-78), is a cell surface glycoprotein that has an important role in cell adhesion $(76,79,80)$. CD56 is expressed on neurons and skeletal muscle cells $(77,81,82)$, and within the human hematopoietic system on NK cells, a subset of T cells, monocytes and dendritic cells (83-85). While being absent from normal plasma cells (86), MM cells from the majority of patients express CD56 (38, 87, 88). Notably, CD56-negative MM is associated with reduced bone destruction $(89,90)$, but increased frequency of extramedullary spread including plasma cell leukemia $(91,92)$.

In preclinical studies, lorvotuzumab mertansine impaired the survival of CD56-expressing MM cells in a dose-dependent manner, even when adherent to BMSCs (38). CD56-negative tumor cells were unaffected. Cytotoxicity was associated with G2-M cell arrest and apoptosis. In addition, the ADC induced NK cell-mediated ADCC through its Fc tail (12). Cytotoxicity was not correlated with surface CD56 expression (38). Additional in vitro testing revealed additive-to-synergistic anti-MM effects when combining lorvotuzumab mertansine with thalidomide, dexamethasone, or melphalan (39). Lorvotuzumab mertansine also suppressed tumor growth in mouse models, and combination treatment with either bortezomib or lenalidomide improved the in vivo anti-MM activity of the ADC (40).

The potent preclinical activity formed the rationale for a phase 1 trial in which lorvotuzumab mertansine was evaluated as a single agent in $37 \mathrm{relapsed} /$ refractory patients ( $>3$ prior treatment lines in $78 \%$ of patients) with CD56-positive MM (42). Patients received lorvotuzumab mertansine on days one and eight of a three-week cycle. The MTD was defined as 112 $\mathrm{mg} / \mathrm{m}^{2}$ after two patients experienced a DLT at $140 \mathrm{mg} / \mathrm{m}^{2}$ (grade 3 fatigue, grade 3 renal failure). The toxicity profile was acceptable, although $51 \%$ of patients experienced treatmentrelated peripheral neuropathy (5.3\% grade 3-4). Among 35 patients evaluable for response, anti-MM activity was modest: $5.7 \%$ of patients achieved PR, $11.4 \% \mathrm{MR}$, and $42.9 \%$ SD. Median PFS was 26.1 weeks.

In a second phase 1 trial with relapsed/refractory MM patients (two median prior lines of treatment; 33\% lenalidomide refractory), the combination of lorvotuzumab mertansine (administered on days 1, 8 and 15) with lenalidomide (25 mg on days 1-21) and dexamethasone (40 mg on days $1,8,15$, and 22) in a four-week cycle resulted in an ORR of 59\%, including $31 \%$ of patients with a VGPR or better (41). Again, neuropathy (mostly grade 2 or less) was the most common adverse event. Based on the high incidence of neuropathy and limited efficacy, clinical development of lorvotuzumab mertansine for the treatment of MM was discontinued (93).

\section{STRO-001}

STRO-001 couples the human, aglycosylated CD74-specific IgG1 mAb SP7219 to a cytotoxic maytansinoid payload via a noncleavable linker (43). CD74, a transmembrane glycoprotein which functions as a receptor for macrophage migration inhibitory factor and as a MHC class II chaperone (94), is expressed in the majority of MM cases $(43,95)$. Preclinical studies showed that STRO-001 had anti-MM activity against MM cell lines, as well as in mice (43). In vitro cytotoxicity tended to positively correlate with CD74 expression levels on MM cell surface, but STRO-001 was also active in cell lines with low CD74 expression. Furthermore, STRO-001 was well-tolerated in cynomolgus monkeys at concentrations $\leq 10$ $\mathrm{mg} / \mathrm{kg}$ (serious DLTs at $30 \mathrm{mg} / \mathrm{kg}$ ), despite depletion of B cells and monocytes. Preliminary results from a first-in-human phase 1 trial (NCT03424603) with both 11 relapsed/refractory non-Hodgkin lymphoma (NHL) and $14 \mathrm{MM}$ patients showed that STRO-001 monotherapy was safe. The most common toxicity were chills, fatigue, pyrexia, nausea, cough, and infusion reactions (58\% of adverse events were grade 1 or 2 ) (44). At this moment (highest dose tested: $0.91 \mathrm{mg} / \mathrm{kg}$ ), the MTD has not been reached. One MM patient achieved SD, but up till now no objective responses were observed.

\section{FOR46}

FOR46 consists of the CD46-specific mAb 23AG2 attached to the effector moiety MMAF via a protease-cleavable linker (35). CD46 is a transmembrane glycoprotein that regulates the activity of the complement system by binding and inactivating $\mathrm{C} 3 \mathrm{~b}$ and C4b (96). CD46 is overexpressed on MM cells when compared with non-malignant immune cells $(35,97)$. FOR46 had high and specific cytotoxic activity against MM cell lines and primary MM cells, while non-malignant mononuclear cells were not affected (35). CD46 expression levels correlated positively with the activity of FOR46. Interestingly, because CD46 levels were upregulated on MM cells that were cocultured with BMSCs, FOR46 showed increased killing ability in the presence of BMSCs. Moreover, MM cells from patients with amplification of 1q21 had higher levels of CD46 when compared with samples from patients without this genetic abnormality. This resulted in higher activity of FOR46 in samples from patients with gain of chromosome 1q21, indicating that this ADC may be of particular interest for this high-risk patient group. In mouse models, FOR46 reduced tumor burden in a dose-dependent fashion, and improved survival compared with control mice.

\section{IMMUNOTOXINS}

Contrary to ADCs, immunotoxins have potent protein toxins as payloads. To assure specific targeting, the toxin's native binding domain is replaced using genetic engineering techniques by a $\mathrm{mAb}$ fragment, or another receptor-specific molecule such as a cytokine or growth factor. The general mechanism of action is similar to ADCs: the targeting moiety binds to a specific target on the cell surface, which is followed by internalization of the immunotoxin, after which the toxin interferes with vital cellular processes (Figure 3). Toxins are highly cytotoxic moleculesinternalization of just one molecule into the cytosol is sufficient to induce cell death $(98,99)$. The majority of toxins used in immunotoxin design are either plant- or bacterial based, such as the bacterial pseudomonas exotoxin, diphtheria toxin and Shigalike toxin, and the plant toxins ricin, gelonin and pokeweed 


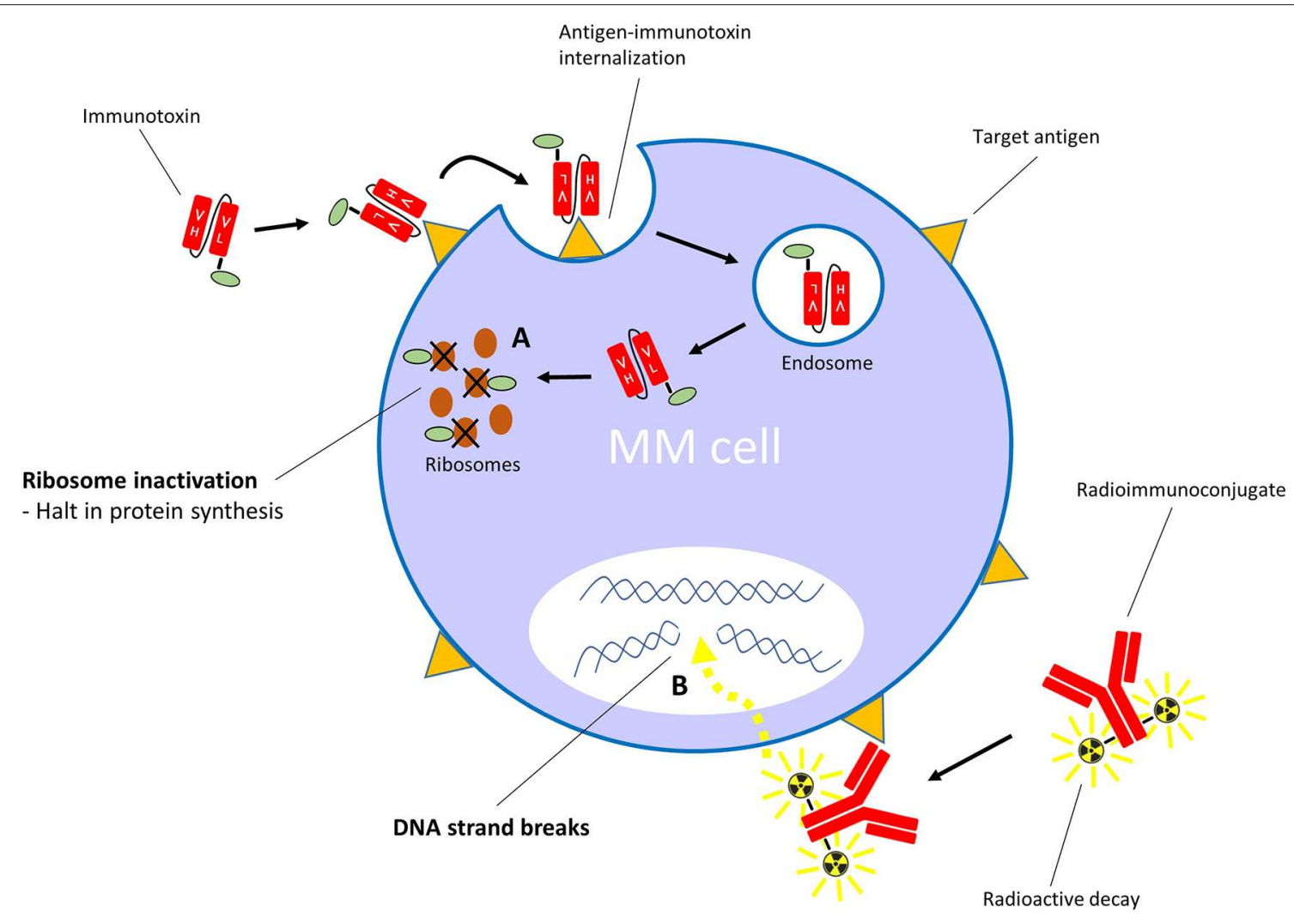

FIGURE 3 | Mechanism of action of immunotoxins with ribosome-inactivating toxins, and radioimmunoconjugates. (A) After binding its specific cell surface target, the immunotoxin is internalized into the cell. The toxin moiety then inactivates ribosomes, which leads to inhibition of polypeptide chain elongation. (B) The

radioimmunoconjugate binds its specific target on the cell surface. Irradiation of cells within the path length of the emitting radionuclide results in DNA strand breaks.

antiviral protein, among many others (100). The majority of toxins belong to the group of ribosome-inactivating proteins, which induce ribotoxic stress, halt protein production and cause subsequent apoptosis (101). This mechanism of action affects both dividing and non-dividing cells. Additionally, accumulating evidence suggests that immunotoxins can induce anti-tumor immune responses (102). A disadvantage of using toxins as payloads is their natural immunogenicity (103), which causes neutralizing anti-toxin antibody responses when administered to patients. However, toxins can be deimmunized by the removal of critical $\mathrm{T}$ cell and $\mathrm{B}$ cell epitopes via genetic engineering $(104,105)$. For an in-depth insight into immunotoxin rationale, design, and advances, we refer to these reviews $(100,106,107)$.

The anti-cancer potential of immunotoxins is illustrated by the FDA-approved drug moxetumomab pasudotox (anti-CD22; Lumoxiti) which showed remarkable efficacy as monotherapy in a phase 3 pivotal clinical trial with relapsed/refractory hairy cell leukemia patients, resulting in a $75 \%$ ORR including 41.3\% complete remission (CR) (108). To date, two additional immunotoxins have been approved by the FDA for the treatment of hematologic malignancies: denileukin difitox (anti-CD25; Ontak; orphan designation granted by EMA) for cutaneous T cell lymphoma and tagraxofusp (anti-CD123; Elzonris; marketing authorization application under review by EMA) for blastic plasmacytoid dendritic cell neoplasm. In the next section, we will focus on the immunotoxins that are or have been under investigation for MM, including one that has recently been translated into a clinical trial.

\section{Immunotoxins Targeting CD38 TAK-169}

TAK-169 is a novel type of recombinant immunotoxin, also called an engineered toxin body (ETB) $(109,110)$. This hybrid molecule is comprised of an anti-CD38 single-chain variable fragment ( $\mathrm{scFv}$ ) fused to the Shiga-like toxin A-subunit (SLTA). CD38 is a transmembrane glycoprotein involved in signaling, adhesion, and ecto-enzymatic processes regulating calcium metabolism $(111,112)$. CD38 is moderately expressed on many hematopoietic cells including NK cells, monocytes, and a fraction of T cells and B cells. Moreover, it is highly expressed on normal and malignant plasma cells $(86,113,114)$, making it an attractive target for anti-MM immunotherapy. Upon binding their target, ETBs force their internalization, and then route retrogradely to the cytosol where they irreversibly inactivate ribosomes resulting in apoptosis. Notably, the SLTA molecules of ETBs are genetically modified to reduce immunogenicity and antidrug antibody responses, without affecting their potency (115, 116). In preclinical studies, TAK-169 potently and specifically 
killed CD38-expressing cell lines and primary MM cells in a dose-dependent manner (109). Additional in vitro data in MM cell lines showed that short $(2 \mathrm{~h})$ exposure to TAK-169 was sufficient for the induction of cytotoxic effects. Notably, TAK-169 binds to a non-overlapping epitope compared with daratumumab, and remains cytotoxic to $\mathrm{MM}$ cells in vitro in the presence of daratumumab. TAK-169 was also effective against CD38-expressing human MM tumors in mouse models. In these mice, the combination of TAK-169 and ixazomib was more effective when compared with the effects of either drug alone. Furthermore, TAK-169 was well-tolerated in cynomolgus monkeys at doses where pharmacodynamic effects (reduction of CD38-positive NK cells) were detected. TAK-169 monotherapy is now being evaluated in a first-in-human phase 1 dose-escalation and -expansion trial with heavily pretreated relapsed/refractory MM patients (NCT04017130) (110). Patient recruitment has started in late 2019.

\section{3-PE38}

This immunotoxin combines an anti-CD38 single domain antibody (nanobody) with $\mathrm{PE} 38$, the $38 \mathrm{kDa}$ version of the pseudomonas exotoxin A (117). 1053-PE38 was highly cytotoxic against MM cell lines in contrast to a non-specific control immunotoxin. Moreover, 1053-PE38 killed primary MM cells isolated from patients in a dose-dependent fashion. Anti-tumor activity was positively correlated with CD38 surface expression levels on target cells. Treatment of target cells with retinoic acid, which increases CD38 expression (118), enhanced their sensitivity to the immunotoxin (117).

\section{Other CD38-Targeting Immunotoxins}

Table 2 provides an overview of the CD38-targeting immunotoxins OKT10-SAP, HB7-blocked ricin, and IB4/saporin-S6. To the best of our knowledge, except for OKT10-SAP, these agents have not been evaluated in clinical trials.

\section{Immunotoxins Targeting Other Markers Leptomycin B-75 (LMB-75) \& Leptomycin B-70 (LMB-70)}

These immunotoxins combine the toxin PE24 with either the fragment antigen-binding ( $\mathrm{Fab})$ part (LMB-70) or the disulfidestabilized (ds)Fv part (LMB-75) of the anti-BCMA mAb BM306 (125-127). PE24 consists of domain III of the pseudomonas exotoxin $\mathrm{A}$ and has reduced immunogenicity as compared with PE38 (130, 131). LMB-70 dose-dependently decreased the viability of BCMA-positive MM cells while having no effects on BCMA-negative cell lines or non-MM cells from patients. In MM cell lines, similar effects were observed with LMB-75 (126). For LMB-70, $10 \mathrm{~min}$ of exposure to the drug was sufficient to kill $>95 \%$ of $\mathrm{MM}$ cells, indicating a rapid, direct toxic effect. Cytotoxicity was associated with cleavage of caspases 3, 8 and 9, and decreased levels of the anti-apoptotic proteins MCL-1 and BCL-XL (125). LMB-70 was also active in MM mouse models

\begin{tabular}{|c|c|c|c|c|c|c|c|}
\hline Drug name & Target & Effector moiety & $\begin{array}{l}\text { Development } \\
\text { state }\end{array}$ & Clinical trial & $\begin{array}{l}\text { Treatment } \\
\text { regimen }\end{array}$ & Status & References \\
\hline TAK-169 & CD38 & SLTA (deimmunized) & Clinical & $\begin{array}{l}\text { NCT04017130; } \\
\text { phase } 1\end{array}$ & TAK-169 mono & Recruiting & $(109,110)$ \\
\hline 1053-PE38 & CD38 & $\begin{array}{l}\text { Pseudomonas exotoxin } \\
\text { A } 38 \mathrm{kDa} \text { fragment } \\
\text { (PE38) }\end{array}$ & Preclinical & - & - & - & $(117)$ \\
\hline IB4/saporin-S6 & CD38 & Saporin-S6 & Preclinical & - & - & - & $(119)$ \\
\hline OKT10-Sap & CD38 & Saporin & Clinical & $\begin{array}{l}\text { Cancer Research } \\
\text { UK trial; phase } 1\end{array}$ & OKT10-Sap mono & - & $(120)$ \\
\hline HB7-blocked ricin & CD38 & Ricin & Preclinical & - & - & - & $(121)$ \\
\hline $\begin{array}{l}\text { ch128.1Av/b-SO6 } \\
\text { (anti-hTfR } \\
\text { lgG3-Av/b-SO6) }\end{array}$ & CD71 & Biotinylated saporin 6 & Preclinical & - & - & - & $(122)$ \\
\hline 2L-Rap-hLL1- $\gamma 4 P$ & CD74 & Frog Rnase & Preclinical & - & - & - & (123) \\
\hline $\begin{array}{l}\text { B-B2-saporin } \\
\text { B-B4-saporin }\end{array}$ & CD138 & Saporin & Preclinical & - & - & - & $(124)$ \\
\hline $\begin{array}{l}\text { LMB-70 } \\
\text { LMB-75 } \\
\text { LMB-38 }\end{array}$ & BCMA (CD269) & $\begin{array}{l}\text { Pseudomonas exotoxin } \\
\text { A domain III (PE24) }\end{array}$ & Preclinical & - & - & - & $(125-127)$ \\
\hline HM1.24-ETA' & CD317 & $\begin{array}{l}\text { Pseudomonas } \\
\text { aeruginosa exotoxin A } \\
\text { (ETA) }\end{array}$ & Preclinical & - & - & - & $(128)$ \\
\hline rGel/BLyS & $\begin{array}{l}\text { BAFF-R (CD268), } \\
\text { TACI (CD267) or } \\
\text { BCMA (CD269) }\end{array}$ & Gelonin, recombinant & Preclinical & - & - & - & (129) \\
\hline
\end{tabular}

mono, monotherapy. 
$(125,127)$. Based on the longer half-life of LMB-70 in mice when compared with LMB-75, LMB-70 may be the most promising candidate for further evaluation in clinical trials.

\section{HM1.24-ETA'}

HM1.24-ETA' is comprised of a CD317-binding scFv linked to a truncated form of the pseudomonas exotoxin A (ETA) (128). CD317 (HM1.24), also called tetherin, is a transmembrane glycoprotein with multiple functions including inhibition of viral particle release from virus-infected cells $(132,133)$ and activation of the NF- $\kappa \mathrm{B}$ pathway $(134,135)$. CD317 is normally expressed on mature B cells, endothelial cells, monocytes and BMSCs $(128,136-138)$. Moreover, it is overexpressed on certain cancer cells including MM (139-142). HM1.24-ETA' efficiently and specifically suppressed the growth of MM cells at nanomolar concentrations via the induction of apoptosis (128). The immunotoxin did not affect the viability of CD317-positive BMSCs and monocytes. Decreased monocyte viability was only observed when monocytes were activated by interferon-gamma, which increases their metabolic state. In mice, HM1.24-ETA' abrogated MM tumor growth.

\section{Other Immunotoxins}

Table 2 summarizes the other immunotoxins that bind CD38, CD138, CD71, CD74, and BAFF receptors.

\section{IMMUNOCYTOKINES}

Immunocytokines are an emerging treatment modality for auto-immune diseases and cancer $(143,144)$. They are comprised of mAbs or $\mathrm{mAb}$ fragments which are fused to either pro-inflammatory or anti-inflammatory cytokine moieties. Although certain cytokines display substantial direct and indirect anti-cancer effects, their use in the clinic is limited by their short half-life in the circulation and severe dose-dependent adverse effects that occur upon systemic administration of free cytokines in therapeutic relevant doses (145). Immunocytokines intend to increase the therapeutic window compared with free cytokines by specifically increasing cytokine concentrations at tumor sites while limiting off-target toxicities at non-tumor sites. When the mAb or mAb fragment binds to its specific antigen, the conjugated cytokine can signal via its native cytokine-receptor to modulate intracellular signaling pathways (Figure 4). An additional benefit of fusing cytokines to mAbs is their increased half-life in the circulation when compared with free cytokines (146). Also, some immunocytokines retain the ability to induce Fc-mediated effector functions (147). Notably, unmodified cytokines conjugated to mAbs retain a high affinity for their native receptors, which precludes total immunocytokine specificity for the target cells.

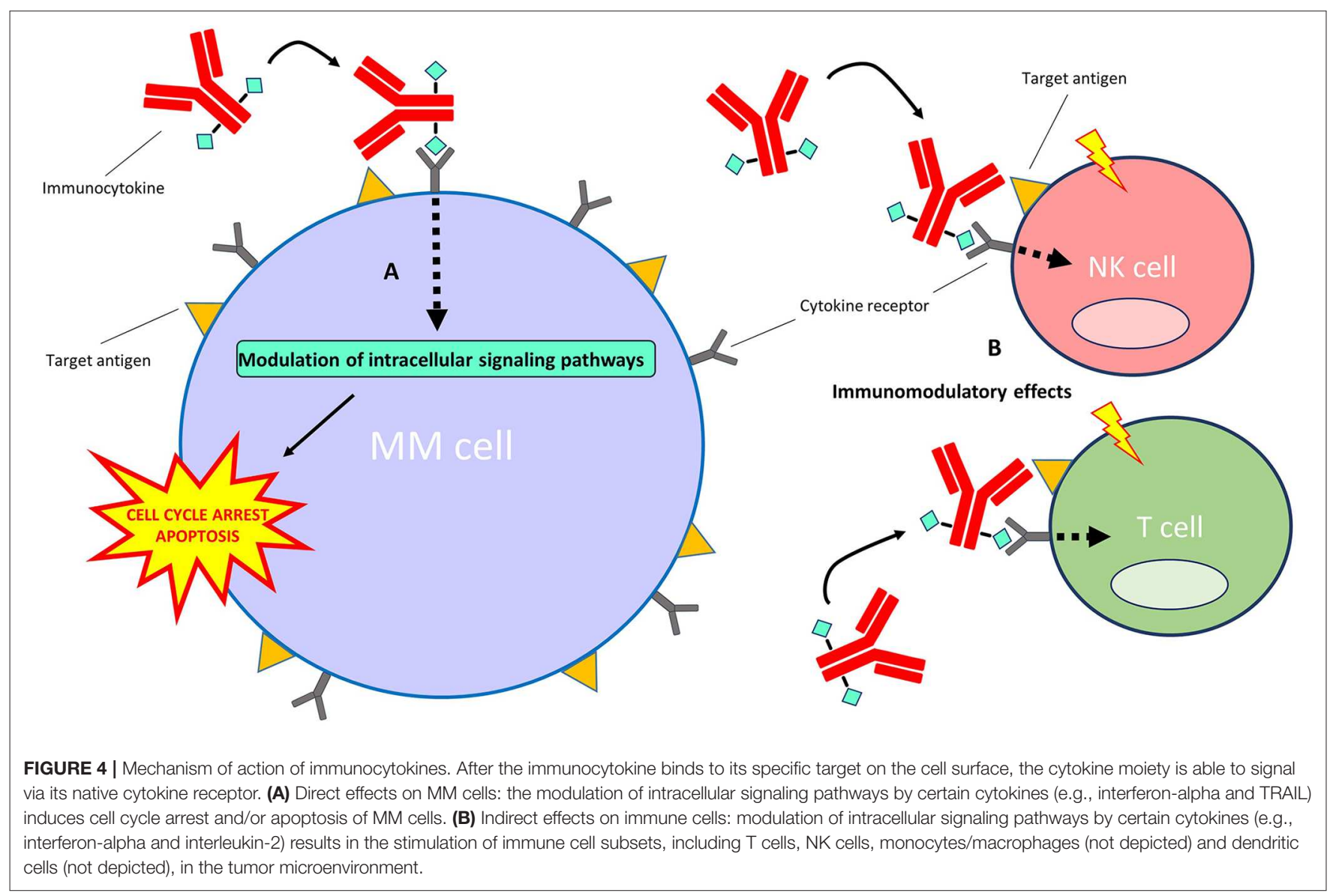


Despite their emergence as an immunotherapeutic drug group, to the best of our knowledge, to date no immunocytokine has been approved by the FDA or EMA for the treatment of cancer. However, with regards to MM, several free cytokines such as interferon-alpha (IFN $\alpha)$ and TNF-related apoptosisinducing ligand (TRAIL) have been extensively studied as a treatment modality because of their known anti-MM effects in preclinical models (148-151). Especially IFN $\alpha$ demonstrates pleiotropic anti-tumor activity by directly inducing apoptosis and growth inhibition of MM cells (152), by indirectly stimulating innate and adaptive immune responses $(153,154)$ and inhibiting angiogenesis $(155,156)$. Despite the clinical benefit of adding IFN $\alpha$ to induction treatment or as maintenance therapy in MM patients (157), substantial dose-related side effects resulted in treatment discontinuation in a high proportion of patients (158, 159). However, to reduce toxicity, IFN $\alpha$ can also be conjugated to MM cell-targeting antibodies (147, 160-163).

In the next section, we will discuss five immunocytokines which are or have been under investigation in MM. Table 3 lists three additional anti-MM immunocytokines that bind HLA-DR, CD20/HLA-DR, and fibronectin extra-domain B.

\section{Immunocytokines Targeting CD38 \\ TAK-573}

TAK-573 (CD38-Attenukine ${ }^{\mathrm{TM}}$ ) is comprised of a CD38-specific IgG4 mAb fused to an attenuated form of human IFN $\alpha 2 b$ (162). This mutated IFN $\alpha 2 b$ component has decreased affinity for the universally expressed IFN $\alpha$ receptor (IFNAR). Accordingly, TAK-573 displays a high specificity for CD38-expressing cells, while having limited activity on CD38-negative cells. In vitro, TAK-573 decreased the growth of CD38-positive MM cell lines, while having minimal effects on the viability of CD38negative cells or the colony formation of normal bone marrow cells. In mouse models, the immunocytokine eliminated CD38expressing $\mathrm{MM}$ and lymphoma tumors, and had synergistic activity when combined with bortezomib or lenalidomide. TAK573 treated mice showed an influx of antitumor M1 macrophages in the tumor microenvironment. These macrophages were possibly attracted by IFN $\alpha$-induced chemokines (164). TAK-573 is currently being studied as monotherapy or in combination with dexamethasone in a phase $1 / 2$ trial with heavily pretreated MM patients (NCT03215030).

\section{IL2- $\alpha$ CD38- $\alpha$ CD38-scTRAIL}

This immunocytokine consists of the anti-CD38 scFv of the mAb daratumumab, in tandem diabody format, concurrently tethered to both interleukin-2 (IL-2) and TRAIL by peptide linkers (165). TRAIL has profound anti-MM activity following interaction with death receptor-4 and -5 (149-151), whereas IL-2 can contribute to antitumor immunity by stimulating cytotoxic CD8-positive $\mathrm{T}$ cells and NK cells in the tumor microenvironment (167, 168). IL2- $\alpha$ CD38- $\alpha$ CD38-scTRAIL specifically binds to CD38 on target cells resulting in reduced viability of MM cells (165).

\section{Other Immunocytokines \\ Anti-CD138-IFN $\alpha 2$, Anti-CD138-IFN $\alpha 2^{\mathrm{YNS}}$, and Anti-CD138-IFN $\alpha 14$}

These immunocytokines combine the specificity of an anti-CD138 IgG1 mAb with the anti-MM activity of an IFN $\alpha 14$, IFN $\alpha 2$, or IFN $\alpha 2^{\text {YNS }}$ (high-affinity IFN $\alpha 2$ mutant) moiety $(161,163)$. Preclinical studies showed that these immunocytokines had higher anti-MM activity against MM cell lines compared with an antiCD20-IFNa2 control immunocytokine. Treatment was associated with a decreased expression of IFN regulatory factor 4 (IRF4), which is a survival factor for MM cells (169, 170). Notably, synergistic activity was observed when immunocytokines were combined with bortezomib (163). In mice, treatment with either immunocytokine reduced MM tumor growth and prolonged survival, and cotreatment of anti-CD138-IFN $\alpha 14$ with bortezomib further improved antitumor activity compared with either treatment alone. Although anti-CD138-IFN $\alpha 2 b$ YNS had stronger anti-MM activity at lower concentrations in vitro compared with anti-CD138-IFN $\alpha 2$, their efficacy was similar in mice.

TABLE 3 | List of immunocytokines investigated for multiple myeloma.

\begin{tabular}{|c|c|c|c|c|c|c|c|}
\hline Drug name & Target & Effector moiety & $\begin{array}{l}\text { Development } \\
\text { state }\end{array}$ & Clinical trial & $\begin{array}{l}\text { Treatment } \\
\text { regimen }\end{array}$ & Status & References \\
\hline TAK-573 & CD38 & $\begin{array}{l}\text { Attenuated IFNa2b } \\
\text { (Attenukine }{ }^{T M} \text { ) }\end{array}$ & Clinical & $\begin{array}{l}\text { NCT03215030; } \\
\text { phase 1/2 }\end{array}$ & $\begin{array}{l}\text { TAK-573 mono } \\
\text { and TAK-573+ } \\
\text { dex }\end{array}$ & Recruiting & $(162,164)$ \\
\hline IL2- $\alpha$ CD38- $\alpha$ CD38-scTRAIL & CD38 & TRAIL \& IL-2 & Preclinical & - & - & - & (165) \\
\hline $\begin{array}{l}\text { Anti-CD138-IFN } \alpha 14 \\
\text { Anti-CD138-IFNa2 } \\
\text { Anti-CD138-IFN } \alpha 2 \text { YNS }\end{array}$ & CD138 & $\begin{array}{l}\text { IFN } \alpha 14 \\
\text { IFN } \alpha 2 \\
\text { IFN } \alpha 2 \text { YNS }\end{array}$ & Preclinical & - & - & - & $(161,163)$ \\
\hline $20-c 2-2 b$ & CD20 \& HLA-DR & IFNa2b & Preclinical & - & - & - & (160) \\
\hline$c 2-2 b-2 b$ & HLA-DR & Tetrameric IFNa2b & Preclinical & - & - & - & (147) \\
\hline $\begin{array}{l}\text { L19-TNF } \alpha \\
\text { L19-IL2 }\end{array}$ & $\begin{array}{l}\text { Fibronectin } \\
\text { extra-domain B }\end{array}$ & $\begin{array}{l}\text { TFN } \alpha \\
\text { IL-2 }\end{array}$ & Preclinical & - & - & - & (166) \\
\hline
\end{tabular}

dex, dexamethasone; mono, monotherapy. 


\section{RADIOIMMUNOCONJUGATES}

Radioimmunoconjugates, also known as antibody-radionuclide conjugates, consist of a mAb which is linked to a radionuclide $(171,172)$. Next to their application in cancer imaging (173$175)$, these radioactive fusion proteins are increasingly explored as a treatment modality for cancer. In contrast to ADCs and immunotoxins, radioimmunoconjugates do not require endocytosis to induce anti-cancer activity. When the $\mathrm{mAb}$ fragment binds its specific antigen, the emitting radionuclide causes DNA strand breaks in the target cell (Figure 3). In addition, depending on the path length of the decaying radionuclide, radioimmunoconjugates can also cause radiation of bystander cells via crossfire effects. A variation on this principle is pretargeted radioimmunotherapy (PRIT), in which the (bispecific) antibodies (containing a radionuclide binding site) and radionuclides are separately delivered to the tumor sites in a multi-step approach $(176,177)$. Anti-MM PRIT agents will not be discussed in detail in this review. As effector moieties, most radioimmunoconjugates contain either alpha particle- or beta particle-emitting radionuclides. Radioimmunoconjugates fused to alpha-emitters are increasingly evaluated for the treatment of hematologic malignancies because of their shorter path length and higher rate of linear energy transfer when compared with beta-emitters. Common toxicities by radioimmunoconjugates are mainly seen in the bone marrow, kidney, and liver. Currently, yttrium-90-ibritumomab tiuxetan (anti-CD20; ${ }^{90} \mathrm{Y}-\mathrm{Zevalin}$ ) is the only radioimmunoconjugate approved by the FDA and EMA for the treatment of follicular B cell NHL. Similar to lymphoma cells, MM cells display inherent sensitivity to radiation $(178,179)$. In the next section, we will discuss the radioimmunoconjugates which have been assessed in clinical trials, or have shown promise in preclinical models. We also provide an overview of other anti-MM radioimmunoconjugates in Table 4.

\section{CD38-Targeting Radioimmunoconjugates} Actinium-225-Daratumumab

This radioimmunoconjugate is comprised of the anti$\mathrm{CD} 38 \mathrm{mAb}$ daratumumab conjugated to actinium-225 (185). Actinium-225 is an alpha-emitting radionuclide with a half-life of 10 days which causes double-strand DNA breaks (194). Actinium-225-daratumumab binds to CD38-positive cells with similar affinity as unconjugated daratumumab, and specifically eliminates CD38-expressing MM cell lines in vitro. Additionally, the daratumumab-based radioimmunoconjugate retains its full ability to induce ADCC and complement-dependent cytotoxicity. In a MM mouse model, actinium-225-daratumumab had tumor-stabilizing

TABLE 4 | List of radioimmunoconjugates investigated for multiple myeloma.

\begin{tabular}{|c|c|c|c|c|c|c|c|}
\hline Drug name & Target & Effector moiety & $\begin{array}{l}\text { Development } \\
\text { state }\end{array}$ & Clinical trial & Treatment regimen & Status & References \\
\hline $\begin{array}{l}\text { Bexxar (iodine- } \\
\text { 131-tositumomab) }\end{array}$ & CD20 & lodine-131 & Clinical & $\begin{array}{l}\text { NCT00135200; } \\
\text { phase } 2\end{array}$ & $\begin{array}{l}\text { Bexxar mono as } \\
\text { consolidation treatment }\end{array}$ & $\begin{array}{l}\text { Active, not } \\
\text { recruiting }\end{array}$ & $(180,181)$ \\
\hline \multirow{2}{*}{$\begin{array}{l}{ }^{90} \text { Y-Zevalin } \\
\text { (yttrium-90- } \\
\text { ibritumomab } \\
\text { tiuxetan) }\end{array}$} & CD20 & Yttrium-90 & Clinical & $\begin{array}{l}\text { NCT00477815; } \\
\text { phase } 1\end{array}$ & $\begin{array}{l}{ }^{90} \text { Y-Zevalin as part of } \\
\text { standard MA } \\
\text { ASCT-conditioning }\end{array}$ & Completed & $(182,183)$ \\
\hline & & & & $\begin{array}{l}\text { NCT01207765; } \\
\text { phase } 2\end{array}$ & $\begin{array}{l}{ }^{90} \text { Y-Zevalin as part of } \\
\text { standard } \\
\text { MA ASCT-conditioning }\end{array}$ & $\begin{array}{l}\text { Terminated } \\
\text { (changes } \\
\text { in practice) }\end{array}$ & \\
\hline $\begin{array}{l}\text { Actinium-225- } \\
\text { lintuzumab }\end{array}$ & CD33 & Actinium-225 & Clinical & $\begin{array}{l}\text { NCT02998047; } \\
\text { phase } 1\end{array}$ & $\begin{array}{l}\text { Actinium-225-lintuzumab } \\
\text { mono }\end{array}$ & Recruiting & $(184)$ \\
\hline $\begin{array}{l}\text { Actinium-225- } \\
\text { daratumumab }\end{array}$ & CD38 & Actinium-225 & Preclinical & - & - & - & $(185)$ \\
\hline $\begin{array}{l}\text { Astatine-221- } \\
\text { CD38 }\end{array}$ & CD38 & Astatine-211 & Preclinical & - & - & - & $(186)$ \\
\hline $\begin{array}{l}\text { Bismuth-213- } \\
\text { anti-CD38 }\end{array}$ & CD38 & Bismuth-213 & Preclinical & - & - & - & $(187)$ \\
\hline $\begin{array}{l}\text { Lead-212- } \\
\text { daratumumab }\end{array}$ & CD38 & Lead $(\mathrm{Pb})-212$ & Preclinical & - & - & - & $(188)$ \\
\hline lodine-131-B-B4 & CD138 & lodine-131 & Clinical & $\begin{array}{l}\text { NCT01296204; } \\
\text { phase } 1\end{array}$ & lodine-131-B-B4 mono & Completed & (189) \\
\hline $\begin{array}{l}\text { Bismuth-213- } \\
\text { B-B4 }\end{array}$ & CD138 & Bismuth-213 & Preclinical & - & - & - & $(190,191)$ \\
\hline $\begin{array}{l}\text { Bismuth-213- } \\
\text { 9E7.4 }\end{array}$ & CD138 & Bismuth-213 & Preclinical & - & - & - & $(192,193)$ \\
\hline $\begin{array}{l}\text { Lutetium-177- } \\
\text { 9E7.4 }\end{array}$ & CD138 & Lutetium-177 & Preclinical & - & - & - & (193) \\
\hline $\begin{array}{l}\text { Bismuth-213- } \\
\text { MA5 }\end{array}$ & MUC1 & Bismuth-213 & Preclinical & - & - & - & (191) \\
\hline
\end{tabular}

ASCT, autologous stem cell transplantation; MA, myeloablative; mono, monotherapy. 
effects at concentrations at which unconjugated daratumumab lacked any activity. Similar to unconjugated daratumumab, the radioimmunoconjugate caused no profound toxicity in vivo (185).

\section{Astatine-211-OKT10-B10 ( ${ }^{211}$ At-CD38)}

This radioimmunoconjugate is composed of the anti-CD38 IgG1 mAb OKT10 fused to the alpha-emitting radionuclide astatine-221 (186). Similar to actinium-225, astatine-211 causes double-strand DNA breaks but has a considerably shorter half-life of $7.2 \mathrm{~h}$ (195). In preclinical evaluation, astatine-211OKT10-B10 was specifically cytotoxic against CD38-positive MM cells. In mouse models, the radioimmunoconjugate showed beneficial tumor-to-normal-organ ratios of radiation uptake and no signs of significant toxicity. Moreover, astatine-211-OKT10B10 demonstrated robust and durable disease eradication in disseminated MM models, and delayed tumor growth in subcutaneous MM models (186). O'Steen and coworkers describe a planned phase 1 clinical trial with $\mathrm{MM}$ patients in which astatine-211-OKT10-B10 will be evaluated in combination with an ASCT-conditioning regimen.

\section{Other Radioimmunoconjugates} Actinium-225-Lintuzumab

Actinium-225-lintuzumab consists of the humanized CD33binding $\mathrm{mAb}$ lintuzumab coupled to the radionuclide actinium225 (184). Although the transmembrane receptor CD33 is generally considered a myeloid lineage marker, it is also expressed on malignant plasma cells of $18-33 \%$ of MM patients. Moreover, CD33-positive MM is associated with unfavorable cytogenetics and poor prognosis (196-198). Clinical evaluation of actinium225-lintuzumab monotherapy in a single-center, phase 1 doseescalation trial with relapsed/refractory MM patients is currently ongoing (184). Patients with $\geq 25 \%$ of MM cells expressing CD33 and with at least three prior lines of treatment are eligible for inclusion.

\section{Bexxar (lodine-131-Tositumomab)}

Bexxar comprises the murine anti-CD20 IgG2 mAb tositumomab conjugated to iodine-131 $(180,181)$. Iodine-131 is a betaemitting radionuclide commonly used for the treatment of thyroid cancer (199). It has a path length of $1-2 \mathrm{~mm}$ and a decay half-life 8 days. CD20 is a cell surface phosphoprotein generally considered as a B cell marker but is also present on malignant plasma cells in $\sim 20 \%$ of MM patients (200-202). Single-dose Bexxar monotherapy was evaluated in a single-center phase 2 study as a consolidation approach in MM patients who had achieved at least PR (but no CR) following at least one prior therapy, regardless of CD20 status (181). Preliminary results report the inclusion of 16 patients (median of two lines of prior treatment) of which six patients (38\%) had CD20-positive MM. Most reported grade 3-4 adverse events were neutropenia (44\%), thrombocytopenia (25\%) and infection (12.5\%). Bexxar improved response ( $\geq 25 \%$ reduction in M-protein) in $67 \%$ and $10 \%$ of patients with CD20-positive or CD20-negative MM, respectively. Two patients with CD20-positive MM achieved a stringent CR. In August 2013, GlaxoSmithKline announced to discontinue the manufacturing of Bexxar, which was followed by a withdrawal of the FDA approval in October 2013 (203).

\section{${ }^{90}$ Y-Zevalin (yttrium-90-ibritumomab tiuxetan)}

${ }^{90} \mathrm{Y}-$ Zevalin is a fusion protein of the CD20-specific IgG1 mAb ibritumomab, linked to the radionuclide yttrium-90 $(182,183)$. Yttrium-90 is a beta-emitter with a mean path length of $5 \mathrm{~mm}$ and a half-life of 64 hours (204). Thus, ${ }^{90} \mathrm{Y}$-Zevalin kills both CD20-positive MM cells and CD20-negative bystander MM cells. ${ }^{90} \mathrm{Y}$-Zevalin (administered on day-14) was evaluated in a singlecenter, dose-escalation phase 1 trial in combination with highdose melphalan (day-2 and-1) prior to ASCT (day 0) in $30 \mathrm{MM}$ patients (183). Three patients experienced a DLT (one at $16 \mathrm{~Gy}$, two at $20 \mathrm{~Gy}$ ), and all patients experienced grade 4 hematologic adverse events. The MTD of this conditioning regimen was defined as 18 Gy. The ORR was $73 \%$, with $63 \%$ achieving a VGPR or better. A subsequent phase 2 trial in which ${ }^{90} \mathrm{Y}-\mathrm{Zevalin}$ was assessed in MM patients with an incomplete response prior to ASCT was prematurely terminated because of a high rate of bacterial infections (182).

\section{lodine-131-B-B4}

In a proof of concept phase $1 / 2$ trial, a single therapeutic dose of the murine anti-CD138 IgG1 mAb B-B4 coupled to iodine-131 was administrated as monotherapy to three relapsed/refractory MM patients who received at least three prior lines of treatment (189). All three patients experienced transient grade 3 or higher hematologic toxicities, but kidney, liver, or thyroid were not significantly affected. No objective responses were observed, although one patient achieved SD.

\section{CONCLUSIONS AND FUTURE PERSPECTIVES}

The outcome of MM patients refractory to IMiDs, PIs, and naked mAbs (daratumumab and elotuzumab) remains poor (7), which underscores the still unmet need for new anti-MM therapies with novel mechanisms of action. A promising approach toward enhancing the power of mAb-based immunotherapy is to arm these antibodies with potent effector moieties. In the field of hemato-oncology, such immunoconjugates are probably the most advanced "magic bullets," a term coined by Paul Ehrlich in the early 1900s, created to date.

The potential of immunoconjugates is exemplified by the ADC belantamab mafodotin, which induces deep responses with an acceptable toxicity profile as monotherapy in heavily pretreated $\mathrm{MM}$ patients, including patients refractory to IMiDs, PIs, and naked anti-CD38 mAbs. Based on these observations, we expect that immunoconjugates will be increasingly evaluated in earlier lines of MM treatment, and that some will become powerful permanent players in the "immunotherapeutic arena." Importantly, several preclinical studies show that many immunoconjugates have additive or even synergistic activity when combined with IMiDs and PIs. In this respect, belantamab mafodotin is currently being assessed in combination with IMiDs, PIs and novel anti-cancer agents (see Table 1). Notably, many immunoconjugates have 
non-overlapping toxicity profiles with IMiDs and PIs, which may allow for tolerable combination treatments. Furthermore, it would be of interest to elucidate whether drugs from different immunoconjugate subgroups can be effectively combined. Because some immunotoxins show in vitro synergy with microtubule-inhibiting taxanes $(125,205)$, a similar effect can be envisioned when immunotoxins are combined with ADCs that contain a microtubule-disrupting payload.

Despite their potential as effective anti-MM agents, immunoconjugates also have their limitations. First, immunoconjugates can cause substantial on- or off-target side effects, which is illustrated by eye toxicity induced by belantamab mafodotin and peripheral neuropathy associated with lorvotuzumab mertansine treatment. Notably, not only the type of target, antibody, and linker, but also the type of effector moiety has an impact on the tolerability profile of immunoconjugates. It is therefore important to combine immunoconjugates with anti-MM drugs with non-overlapping toxicity profiles to avoid additive toxicities. We expect that the identification of novel targets and payloads with reduced non-specific uptake may contribute to decreased toxicity of immunoconjugates in the future. Eventually, the comparison of immunoconjugates with different components in preclinical and clinical studies will point out which mechanism of action is most important in eliminating MM cells, while minimizing the effects on normal tissues.

Second, it is important to take into account the rapid clinical development of other forms of immunotherapy, such as the $\mathrm{T}$ cell redirecting therapies. Indeed, BCMA-directed CAR-T cells and bispecific antibodies have superior activity as monotherapy in heavily pretreated MM patients, when compared with belantamab mafodotin $(64-66,206)$. However, in a subset of patients these therapies are associated with substantial side effects, such as cytokine release syndrome and neurotoxicity. Furthermore, CAR-T cells are currently not available "off-theshelf," as opposed to mAb-based immunotherapies. Also, in patients with age-, tumor- or therapy-related impairment of the T cell compartment (207-212), CAR-T cells and bispecific antibodies may be less effective than therapies inducing direct cytotoxic effects. It would be of interest to explore whether these 'immunologically frail' patients benefit more from mAbs armed with powerful effector moieties, such as small molecule drugs, toxins, or radionuclides.

Finally, several mechanisms of resistance may limit the efficacy of immunoconjugates. Target antigen expression is an important factor for target recognition and effector function by mAbs (213). There is considerable heterogeneity in expression of target antigens between MM patients (16, 213-218). Patients with low levels of target antigen on the tumor cell surface are at increased risk of treatment failure (213). Furthermore, MM cells may lack expression of the target antigen [e.g., 20\% of $\mathrm{MM}$ is CD56-negative $(38,87,88)$ ], which will probably be associated with primary resistance to immunoconjugates. Screening for target antigen expression prior to initiation of treatment may be critical in case response is associated with expression levels, and if a substantial fraction of patients lack expression of the target antigen. In addition, progression after prior response may be related to downregulation of the target antigen, which has been shown to contribute to the development of resistance to CD38 antibody treatment (213) and BCMAtargeted $\mathrm{T}$ cell redirecting therapy $(216,219,220)$. Also, MM is characterized by substantial intraclonal heterogeneity, and outgrowth of a subclone with low target expression may also result in development of disease progression. It is currently unknown to what extent antigen expression levels at baseline and at the time of progression contribute to immunoconjugateresistance, and further studies are needed to increase our understanding of the impact of antigen expression on primary or acquired resistance to immunoconjugates. Recent studies, especially with ADCs and immunotoxins in other cancers than MM, demonstrate that other potential mechanisms of resistance to immunoconjugates include: (1) increased payload efflux from the cells by drug efflux pumps, such as multidrug resistance protein 1 (MDR1, P-glycoprotein), (2) defects in intracellular trafficking pathways, (3) increased ADC/antigen complex recycling, and (4) activation of anti-apoptotic-or other intracellular signaling pathways $(221,222)$. Importantly, better insight into those resistance mechanisms may facilitate improvements in immunoconjugate design, and provide a rationale for more efficacious combination strategies. Besides the possible benefit of combining immunoconjugates with IMiDs and PIs, other agents that directly counteract resistance mechanisms may be used. For example, some research groups are exploring the combination of ADCs with MDR1-inhibitors to prevent payload efflux (223-225). As another strategy, immunoconjugates can be combined with drugs that increase the surface expression of the target antigen. For instance, the combination of belantamab mafodotin with a gammasecretase inhibitor, which increases BCMA density on MM cells, may impede the in vivo escape of subclones with low BCMA expression, thereby preventing or delaying disease progression (20). A similar strategy can be envisioned by combining CD38-specific immunoconjugates with agents that increase CD38 expression such as ATRA, panobinostat, or DNA methyltransferases $(118,226,227)$. Identification of novel targets for immunoconjugates may also be important to address interpatient heterogeneity and antigen escape. Potential new targets, such as GPRC5D $(215,217)$, should be uniformly expressed on MM cells, and not on critical healthy tissues.

In summary, immunoconjugates are versatile immunotherapeutic agents with pleiotropic mechanisms of action. Depending on the effector moiety and mAb characteristics, these may include direct pro-apoptotic/antiproliferative effects, indirect Fc-mediated effects (ADCC and ADCP), and indirect immunomodulatory effects. The ADC belantamab mafodotin is the first in its class to show potent anti-MM activity in clinical trials (17-19). Encouraging results from the ever-growing list of preclinical and clinical studies with immunoconjugates demonstrate that this drug group holds promise as a treatment strategy for MM patients. Moreover, 
the immunoconjugate development field is rapidly progressing with the identification of novel targets, and improvements of payloads and linkers. We expect that targeted therapy with immunoconjugates will be increasingly used in clinical trials, and, soon upon regulatory approval, also outside clinical studies.

\section{REFERENCES}

1. Siegel RL, Miller KD, Jemal A. Cancer statistics, 2016. CA Cancer J Clin. (2016) 66:7-30. doi: 10.3322/caac.21332

2. Bray F, Ferlay J, Soerjomataram I, Siegel RL, Torre LA, Jemal A. Global cancer statistics 2018: GLOBOCAN estimates of incidence and mortality worldwide for 36 cancers in 185 countries. CA Cancer J Clin. (2018) 68:394-424. doi: 10.3322/caac. 21492

3. Keats JJ, Chesi M, Egan JB, Garbitt VM, Palmer SE, Braggio E, et al. Clonal competition with alternating dominance in multiple myeloma. Blood. (2012) 120:1067-76. doi: 10.1182/blood-2012-01-405985

4. Bahlis NJ. Darwinian evolution and tiding clones in multiple myeloma. Blood. (2012) 120:927-8. doi: 10.1182/blood-2012-06-430645

5. Walker BA, Wardell CP, Melchor L, Hulkki S, Potter NE, Johnson DC, et al. Intraclonal heterogeneity and distinct molecular mechanisms characterize the development of $\mathrm{t}(4 ; 14)$ and $\mathrm{t}(11 ; 14)$ myeloma. Blood. (2012) 120:107786. doi: 10.1182/blood-2012-03-412981

6. Palumbo A, Avet-Loiseau H, Oliva S, Lokhorst HM, Goldschmidt H, Rosinol $\mathrm{L}$, et al. Revised international staging system for multiple myeloma: a report from international myeloma working group. JCO. (2015) 33:2863-9. doi: 10.1200/JCO.2015.61.2267

7. Gandhi UH, Cornell RF, Lakshman A, Gahvari ZJ, McGehee E, Jagosky $\mathrm{MH}$, et al. Outcomes of patients with multiple myeloma refractory to CD38-targeted monoclonal antibody therapy. Leukemia. (2019) 33:2266-75. doi: 10.1038/s41375-019-0435-7

8. Schrama D, Reisfeld RA, Becker JC. Antibody targeted drugs as cancer therapeutics. Nat Rev Drug Discov. (2006) 5:147-59. doi: 10.1038/nrd1957

9. Tolcher AW. Antibody drug conjugates: lessons from 20 years of clinical experience. Ann Oncol. (2016) 27:2168-72. doi: 10.1093/annonc/mdw424

10. Yu B, Liu D. Antibody-drug conjugates in clinical trials for lymphoid malignancies and multiple myeloma. J Hematol Oncol. (2019) 12:94. doi: 10.1186/s13045-019-0786-6

11. Chau CH, Steeg PS, Figg WD. Antibody-drug conjugates for cancer. Lancet. (2019) 394:793-804. doi: 10.1016/S0140-6736(19)31774-X

12. Skaletskaya A, Setiady YY, Park PU, Lutz RJ. Abstract 770: lorvotuzumab mertansine (IMGN901) immune effector activity and its effect on human NK cells. Cancer Res. (2011) 71(8 Suppl.):770. doi: 10.1158/1538-7445.AM2011-770

13. Tai Y-T, Mayes PA, Acharya C, Zhong MY, Cea M, Cagnetta A, et al. Novel anti-B-cell maturation antigen antibody-drug conjugate (GSK2857916) selectively induces killing of multiple myeloma. Blood. (2014) 123:3128-38. doi: 10.1182/blood-2013-10-535088

14. Pahl A, Lutz C, Hechler T. Amanitins and their development as a payload for antibody-drug conjugates. Drug Discov Today. (2018) 30:85-9. doi: 10.1016/j.ddtec.2018.08.005

15. Decarvalho S, Rand HJ, Lewis A. Coupling of cyclic chemotherapeutic Compounds to Immune Gamma-Globulins. Nature. (1964) 202:255-8. doi: $10.1038 / 202255 \mathrm{a} 0$

16. Lee L, Bounds D, Paterson J, Herledan G, Sully K, Seestaller-Wehr LM, et al. Evaluation of B cell maturation antigen as a target for antibody drug conjugate mediated cytotoxicity in multiple myeloma. Br J Haematol. (2016) 174:911-22. doi: 10.1111/bjh.14145

17. Trudel S, Lendvai N, Popat R, Voorhees PM, Reeves B, Libby EN, et al. Targeting B-cell maturation antigen with GSK2857916 antibody-drug conjugate in relapsed or refractory multiple myeloma (BMA117159): a dose escalation and expansion phase 1 trial. Lancet Oncol. (2018) 19:1641-53. doi: 10.1016/S1470-2045(18)30576-X

\section{AUTHOR CONTRIBUTIONS}

WB (literature research) and ND (supervision) prepared the first draft of the manuscript. TM and SZ critically reviewed the manuscript. All authors edited the manuscript and checked the final version of it.

18. Trudel S, Lendvai N, Popat R, Voorhees PM, Reeves B, Libby EN, et al. Antibody-drug conjugate, GSK2857916, in relapsed/refractory multiple myeloma: an update on safety and efficacy from dose expansion phase I study. Blood Cancer J. (2019) 9:1-10. doi: 10.1038/s41408-019-0196-6

19. Lonial S, Lee HC, Badros A, Trudel S, Nooka AK, Chari A, et al. Belantamab mafodotin for relapsed or refractory multiple myeloma (DREAMM-2): a two-arm, randomised, open-label, phase 2 study. Lancet Oncol. (2019) 21:207-21. doi: 10.1016/S1470-2045(19)30788-0

20. Eastman S. Synergistic activity of belantamab mafodotin (anti-BCMA immuno-conjugate) with PF-03084014 (gamma-secretase inhibitor) in Bcma-expressing cancer cell lines. In: 61st Annual Meeting and Exposition. Orlando, FL: American Society of Hematology (2019). doi: 10.1182/blood-2019-123705

21. Montes de Oca R, Bhattacharya S, Vitali N, Patel K, Kaczynski H, Shi $\mathrm{HZ}$, et al. Abstract \#PF558: the anti-BCMA antibody-drug conjugate GSK2857916 drives immunogenic cell death and immune-mediated antitumor responses, and in combination with an OX40 agonist potentiates in vivo activity. In: European Hematology Association Annual Meeting. Amsterdam (2019). doi: 10.1097/01.HS9.0000560524.63281.bc

22. Kinneer K, Meekin J, Varkey R, Xiao X, Zhong H, Breen S. Preclinical evaluation of MEDI2228, a BCMA-targeting pyrrolobenzodiazepine-linked antibody drug conjugate for the treatment of multiple myeloma. Blood. (2017) 130(Suppl. 1):3153. doi: 10.1182/blood.V130.Suppl_1.3153.3153

23. Tai Y-T, Xing L, Lin L, Yu T, Cho S-F, Wen K, et al. MEDI2228, a novel BCMA pyrrolobenzodiazepine antibody drug conjugate, overcomes drug resistance and synergizes with bortezomib and DNA damage response inhibitors in multiple myeloma. Clin Lymphoma Myeloma Leuk. (2019) 19:e154-5. doi: 10.1016/j.clml.2019.09.257

24. Kinneer K, Flynn M, Thomas SB, Meekin J, Varkey R, Xiao X, et al. Preclinical assessment of an antibody-PBD conjugate that targets BCMA on multiple myeloma and myeloma progenitor cells. Leukemia. (2019) 33:766-71. doi: 10.1038/s41375-018-0278-7

25. Xing L, Lin L, Yu T, Li Y, Cho S-F, Liu J, et al. A novel BCMA PBD-ADC with ATM/ATR/WEE1 inhibitors or bortezomib induce synergistic lethality in multiple myeloma. Leukemia. (2020) 1-13. doi: 10.1038/s41375-020-0745-9

26. Xing L. Anti-bcma PBD MEDI2228 combats drug resistance and synergizes with Bortezomib and inhibitors to DNA damagce response in multiple myeloma. In: 61st Annual Meeting and Exposition. Orlando, FL: American Society of Hematology (2019). doi: 10.1182/blood-2019-127163

27. Hechler T, Palfi A, Müller C, Lutz C, Pahl A, Kulke M. Abstract 77: preclinical evaluation of HDP-101, an anti-BCMA antibody-drug conjugate. Cancer Res. (2017) 77(13 Suppl.):77. doi: 10.1158/1538-7445.AM2017-77

28. Ko J, Breunig C, Figueroa V, Lehners N, Baumann A, Pálfi A, et al. Preclinical evaluation of HDP-101, a novel anti-BCMA antibody-drug conjugate, in multiple myeloma. Blood. (2017) 130:3070.

29. Singh RK, Jones RJ, Hong S, Shirazi F, Wang H, Kuiatse I, et al. HDP101, a novel B-cell maturation antigen (BCMA)-targeted antibody conjugated to $\alpha$-Amanitin, Is active against myeloma with preferential efficacy against pre-clinical models of deletion 17p. Blood. (2018) 132(Suppl. 1):593. doi: 10.1182/blood-2018-99-118412

30. Pahl A, Ko J, Breunig C, Figueroa V, Lehners N, Baumann A, et al. HDP101: preclinical evaluation of a novel anti-BCMA antibody drug conjugates in multiple myeloma. JCO. Orlando, FL: American Society of Hematology (2018) 36(15_suppl):e14527.doi: 10.1200/JCO.2018.36.15_suppl.e14527

31. Ryan MC, Hering M, Peckham D, McDonagh CF, Brown L, Kim KM, et al. Antibody targeting of B-cell maturation antigen on malignant plasma cells. Mol Cancer Ther. (2007) 6:3009-18. doi: 10.1158/1535-7163.MCT-07-0464 
32. Hau A, Zhu T, Wang R, Lau M, Li L, Li X, et al. Preclinical development of a Bcma targeting antibody-drug conjugate with novel payload for multiple myeloma therapy. Blood. (2019) 134(Suppl. 1):5623. doi: 10.1182/blood-2019-132080

33. Li L, Tong W, Lau M, Fells $\mathrm{K}$, Zhu T, Sun Y, et al. Preclinical development of an Anti-CD38 antibody-drug conjugate for treatment of hematological malignancies. Blood. (2019) 134(Suppl. 1):5621. doi: 10.1182/blood-2019-132062

34. Zhang X, Zhang C, Yang X, Hou X, Zhao W, Benson D, et al. Design, synthesis and evaluation of anti-CD38 antibody drug conjugate based on Daratumumab and maytansinoid. Bioorg Med Chem. (2019) 27:479-82. doi: 10.1016/j.bmc.2018.12.024

35. Sherbenou DW, Aftab BT, Su Y, Behrens CR, Wiita A, Logan AC, et al. Antibody-drug conjugate targeting CD46 eliminates multiple myeloma cells. J Clin Invest. (2016) 126:4640-53. doi: 10.1172/JCI85856

36. Lewis TS, Olson D, Gordon K, Sandall S, Quick M, Finn M, et al. SGN-CD48A: a novel humanized anti-CD48 antibody-drug conjugate for the treatment of multiple myeloma. Blood. (2016) 128:4470. doi: 10.1182/blood.V128.22.4470.4470

37. Olson DJ, Liu BA, Zaval M, Cao A, Gurgel J, Cochran J, et al. Abstract 5619: Additional mechanisms of action of SGN-CD48A in multiple myeloma and improved antitumor activity in combination with daratumumab. Cancer Res. (2018) 78(13 Suppl.):5619. doi: 10.1158/1538-7445.AM2018-5619

38. Tassone P, Gozzini A, Goldmacher V, Shammas MA, Whiteman KR, Carrasco DR, et al. In vitro and in vivo activity of the maytansinoid immunoconjugate huN901-N2'-deacetyl-N2'-(3-mercapto-1-oxopropyl)maytansine against CD56+ multiple myeloma cells. Cancer Res. (2004) 64:4629-36. doi: 10.1158/0008-5472.CAN-04-0142

39. Lutz R, Ab O, Foley K, Goldmacher V, Whiteman K, Xie H, et al. Efficacy of the huN901-DM1 conjugate in combination with antineoplastic agents against multiple myeloma cells in preclinical studies In: 98th AACR Annual Meeting-Apr 14-18. Los Angeles, CA (2007) 67(9 Suppl.):5577.

40. Whiteman K, Ab O, Bartle L, Foley K, Goldmacher V, Lutz R. Efficacy of IMGN901 (huN901-DM1) in combination with bortezomib and lenalidomide against multiple myeloma cells in preclinical studies. In: 99th AACR Annual Meeting-Apr 12-16. San Diego, CA (2008) 68(9 Suppl. ):2146.

41. Berdeja JG, Hernandez-Ilizaliturri F, Chanan-Khan A, Patel M, Kelly $\mathrm{KR}$, Running KL, et al. Phase I study of lorvotuzumab mertansine (LM, IMGN901) in combination with lenalidomide (Len) and dexamethasone (Dex) in patients with CD56-positive relapsed or relapsed/refractory multiple myeloma (MM). Blood. (2012) 120:728. doi: 10.1182/blood.V120.21.728.728

42. Ailawadhi S, Kelly KR, Vescio RA, Jagannath S, Wolf J, Gharibo M, et al. A phase I study to assess the safety and pharmacokinetics of single-agent lorvotuzumab mertansine (IMGN901) in patients with relapsed and/or refractory CD-56-positive multiple myeloma. Clin Lymphoma Myeloma Leuk. (2019) 19:29-34. doi: 10.1016/j.clml.2018.08.018

43. Abrahams CL, Li X, Embry M, Yu A, Krimm S, Krueger S, et al. Targeting CD74 in multiple myeloma with the novel, site-specific antibody-drug conjugate STRO-001. Oncotarget. (2018) 9:37700-14. doi: 10.18632/oncotarget.26491

44. Shah NN, Krishnan AY, Shah ND, Burke JM, Melear JM, Spira AI, et al. Preliminary results of a phase 1 dose escalation study of the first-inclass anti-CD74 antibody drug conjugate (ADC), STRO-001, in patients with advanced B-cell malignancies. Blood. (2019) 134(Suppl_1):5329. doi: 10.1182/blood-2019-122754

45. Sapra P, Stein R, Pickett J, Qu Z, Govindan SV, Cardillo TM, et al. AntiCD74 antibody-doxorubicin conjugate, IMMU-110, in a human multiple myeloma xenograft and in monkeys. Clin Cancer Res. (2005) 11:5257-64. doi: 10.1158/1078-0432.CCR-05-0204

46. Ikeda $H$, Hideshima $T$, Fulciniti M, Lutz RJ, Yasui $H$, Okawa $Y$, et al. The monoclonal antibody nBT062 conjugated to cytotoxic maytansinoids has selective cytotoxicity against CD138-positive multiple myeloma cells in vitro and in vivo. Clin Cancer Res. (2009) 15:4028-37. doi: 10.1038/npre.2008.2374.1

47. Zuber C, Daelken B, Aigner S, Haeder T, Ab O, Whiteman K, et al. BT062, a CD138-specific immunoconjugate, demonstrates superior in vivo antimyeloma efficacy in combination with lenalidomide or bortezomib. Blood. (2010) 116:3008. doi: 10.1182/blood.V116.21.3008.3008
48. Kelly KR, Siegel DS, Chanan-Khan AA, Somlo G, Heffner LT, Jagannath $\mathrm{S}$, et al. Indatuximab Ravtansine (BT062) in combination with low-dose dexamethasone and lenalidomide or pomalidomide: clinical activity in patients with relapsed / refractory multiple myeloma. Blood. (2016) 128:4486. doi: 10.1182/blood.V128.22.4486.4486

49. Schönfeld K, Zuber C, Pinkas J, Häder T, Bernöster K, Uherek C. Indatuximab ravtansine (BT062) combination treatment in multiple myeloma: pre-clinical studies. J Hematol Oncol. (2017) 10:13. doi: 10.1186/s13045-016-0380-0

50. Jagannath S, Heffner LT, Ailawadhi S, Munshi NC, Zimmerman TM, Rosenblatt J, et al. Indatuximab Ravtansine (BT062) monotherapy in patients with relapsed and/or refractory multiple myeloma. Clin Lymphoma Myeloma Leuk. (2019) 19:372-80. doi: 10.1016/j.clml.2019.02.006

51. Tassone P, Goldmacher VS, Neri P, Gozzini A, Shammas MA, Whiteman $\mathrm{KR}$, et al. Cytotoxic activity of the maytansinoid immunoconjugate B-B4DM1 against CD138+ multiple myeloma cells. Blood. (2004) 104:3688-96. doi: 10.1182/blood-2004-03-0963

52. Elkins K, Zheng B, Go M, Slaga D, Du C, Scales SJ, et al. FcRL5 as a target of antibody-drug conjugates for the treatment of multiple myeloma. $\mathrm{Mol}$ Cancer Ther. (2012) 11:2222-32. doi: 10.1158/1535-7163.MCT-12-0087

53. Stewart AK, Krishnan AY, Singhal S, Boccia RV, Patel MR, Niesvizky R, et al. Phase I study of the anti-FcRH5 antibody-drug conjugate DFRF4539A in relapsed or refractory multiple myeloma. Blood Cancer J. (2019) 9:17. doi: 10.1038/s41408-019-0178-8

54. Doronina SO, Toki BE, Torgov MY, Mendelsohn BA, Cerveny CG, Chace DF, et al. Development of potent monoclonal antibody auristatin conjugates for cancer therapy. Nat Biotechnol. (2003) 21:778-84. doi: 10.1038/nbt832

55. Gish K, Kim H, Powers R, Fox M, Hickson J, McGonigal T, et al. Preclinical evaluation of Abbv-838, a first-in-class anti-CS1 antibody-drug conjugate for the treatment of multiple myeloma. In: 21st European Hematology Association Annual Meeting. June 9-12 Copenhagen. (2016) 101:253. Available online at: https://library.ehaweb.org/eha/2016/21st/133532/kurt. gish.preclinical.evaluation.of.abbv-838.a.first-in-class.anti-cs1.html

56. Vij R, Nath R, Afar DEH, Mateos M-V, Berdeja JG, Raab MS, et al. First-inhuman phase I study of ABBV-838, an antibody-drug conjugate targeting SLAMF7/CS1 in patients with relapsed and refractory multiple myeloma. Clin Cancer Res. (2020) 26:2308-17. doi: 10.1158/1078-0432.CCR-19-1431

57. Lewis T, Olson DJ, Gordon KA, Sandall SL, Miyamoto J, Westendorf L, et al. Abstract 1195: SGN-CD352A: a novel humanized anti-CD352 antibodydrug conjugate for the treatment of multiple myeloma. Cancer Res. (2016) 76(14 Suppl.):1195. doi: 10.1158/1538-7445.AM2016-1195

58. Monks NR, Schifferli KP, Tammali R, Borrok MJ, Coats SR, Herbst R, et al. Abstract LB-295: MEDI7247, a novel pyrrolobenzodiazepine ADC targeting ASCT2 with potent in vivo activity across a spectrum of hematological malignancies. Cancer Res. (2018) 78(13 Suppl.): 295. doi: 10.1158/1538-7445.AM2018-LB-295

59. Bertino JR, Lin S-Y, Lin C-Y. Abstract 2596: targeted delivery of doxorubicin conjugated with anti-matriptase antibody to treat multiple myeloma. Cancer Res. (2010) 70(8 Suppl.):2596. doi: 10.1158/1538-7445.AM10-2596

60. Novak AJ, Darce JR, Arendt BK, Harder B, Henderson K, Kindsvogel $\mathrm{W}$, et al. Expression of BCMA, TACI, and BAFF-R in multiple myeloma: a mechanism for growth and survival. Blood. (2004) 103:689-94. doi: 10.1182/blood-2003-06-2043

61. O'Connor BP, Raman VS, Erickson LD, Cook WJ, Weaver LK, Ahonen C, et al. BCMA is essential for the survival of long-lived bone marrow plasma cells. J Exp Med. (2004) 199:91-8. doi: 10.1084/jem.20031330

62. Mackay F, Schneider P, Rennert P, Browning J. BAFF andAPRIL: a tutorial on B cell survival. Annu Rev Immunol. (2003) 21:231-64. doi: 10.1146/annurev.immunol.21.120601.141152

63. Quinn J, Glassford J, Percy L, Munson P, Marafioti T, Rodriguez-Justo M, et al. APRIL promotes cell-cycle progression in primary multiple myeloma cells: influence of D-type cyclin group and translocation status. Blood. (2011) 117:890-901. doi: 10.1182/blood-2010-01-264424

64. Raje N, Berdeja J, Lin Y, Siegel D, Jagannath S, Madduri D, et al. Anti-BCMA CAR T-Cell therapy bb2121 in relapsed or refractory multiple myeloma. $N$ Engl J Med. (2019) 380:1726-37. doi: 10.1056/NEJMoa1817226

65. Costa L. First clinical study of the B-cell maturation antigen (BCMA) $2+1 \mathrm{~T}$ cell engager (TCE) CC-93269 in patients (Pts) with relapsed/refractory multiple myeloma (RRMM): interim results of a phase 1 multicenter trial. 
In: 61st Annual Meeting and Exposition. Orlando, FL: American Society of Hematology (2019). doi: 10.1182/blood-2019-122895

66. Madduri D. Results from CARTITUDE-1: a phase $1 \mathrm{~b} / 2$ study of JNJ-4528, a CAR-T cell therapy directed against B-cell maturation antigen (BCMA), in patients with relapsed and/or refractory multiple myeloma (R/R MM). In: 61st Annual Meeting and Exposition. Orlando, FL: American Society of Hematology (2019). doi: 10.1182/blood-2019-121731

67. Zhao H, Atkinson J, Gulesserian S, Zeng Z, Nater J, Ou J, et al. Modulation of macropinocytosis-mediated internalization decreases ocular toxicity of antibody-drug conjugates. Cancer Res. (2018) 15;78:2115-26. doi: 10.1158/0008-5472.CAN-17-3202

68. Eaton JS, Miller PE, Mannis MJ, Murphy CJ. Ocular adverse events associated with antibody-drug conjugates in human clinical trials. J Ocul Pharmacol Ther. (2015) 31:589-604. doi: 10.1089/jop.2015.0064

69. Heidelberg Pharma AG. Interim Management Statement on the First Nine Months of 2019. [Internet]. (2020) Available online at: https://heidelbergpharma.com/files/20191010_HDP_InterimManagementStatement_ Q3_2019_englfinal.pdf (cited January 6, 2020).

70. Bernfield M, Kokenyesi R, Kato M, Hinkes MT, Spring J, Gallo RL, et al. Biology of the syndecans: a family of transmembrane heparan sulfate proteoglycans. Annu Rev Cell Biol. (1992) 8:365-93. doi: 10.1146/annurev.cb.08.110192.002053

71. Elenius K, Jalkanen M. Function of the syndecans-a family of cell surface proteoglycans. J Cell Sci. (1994) 107(Pt 11):2975-82.

72. Wijdenes J, Vooijs WC, Clément C, Post J, Morard F, Vita N, et al. A plasmocyte selective monoclonal antibody (B-B4) recognizes syndecan-1. Br J Haematol. (1996) 94:318-23. doi: 10.1046/j.1365-2141.1996.d01-1811.x

73. O'Connell FP, Pinkus JL, Pinkus GS. CD138 (Syndecan-1), a plasma cell marker: immunohistochemical profile in hematopoietic and nonhematopoietic neoplasms. Am J Clin Pathol. (2004) 121:254-63. doi: 10.1309/617DWB5GNFWXHW4L

74. Foley EM, Esko JD. Hepatic heparan sulfate proteoglycans and endocytic clearance of triglyceride-rich lipoproteins. Prog Mol Biol Transl Sci. (2010) 93:213-33. doi: 10.1016/S1877-1173(10)93010-X

75. Mahtouk K, Hose D, Raynaud P, Hundemer M, Jourdan M, Jourdan E, et al. Heparanase influences expression and shedding of syndecan1 , and its expression by the bone marrow environment is a bad prognostic factor in multiple myeloma. Blood. (2007) 109:4914-23. doi: 10.1182/blood-2006-08-043232

76. Thiery JP, Brackenbury R, Rutishauser U, Edelman GM. Adhesion among neural cells of the chick embryo. II. Purification and characterization of a cell adhesion molecule from neural retina. J Biol Chem. (1977) 252:6841-5.

77. Cunningham BA, Hemperly JJ, Murray BA, Prediger EA, Brackenbury R, Edelman GM. Neural cell adhesion molecule: structure, immunoglobulin-like domains, cell surface modulation, and alternative RNA splicing. Science. (1987) 236:799-806. doi: 10.1126/science. 3576199

78. Lanier LL, Testi R, Bindl J, Phillips JH. Identity of Leu-19 (CD56) leukocyte differentiation antigen and neural cell adhesion molecule. J Exp Med. (1989) 169:2233-8. doi: 10.1084/jem.169.6.2233

79. Nitta T, Yagita H, Sato K, Okumura K. Involvement of CD56 (NKH-1/Leu19 antigen) as an adhesion molecule in natural killer-target cell interaction. $J$ Exp Med. (1989) 170:1757-61. doi: 10.1084/jem.170.5.1757

80. Edelman GM. Cell adhesion molecules in the regulation of animal form and tissue pattern. Annu Rev Cell Biol. (1986) 2:81-116. doi: 10.1146/annurev.cb.02.110186.000501

81. Schubert W, Zimmermann K, Cramer M, Starzinski-Powitz A. Lymphocyte antigen Leu-19 as a molecular marker of regeneration in human skeletal muscle. Proc Natl Acad Sci USA. (1989) 86:307-11. doi: 10.1073/pnas.86.1.307

82. Illa I, Leon-Monzon M, Dalakas MC. Regenerating and denervated human muscle fibers and satellite cells express neural cell adhesion molecule recognized by monoclonal antibodies to natural killer cells. Ann Neurol. (1992) 31:46-52. doi: 10.1002/ana.410310109

83. Caligiuri MA. Human natural killer cells. Blood. (2008) 112:461-9. doi: 10.1182/blood-2007-09-077438

84. Lanier LL, Le AM, Civin CI, Loken MR, Phillips JH. The relationship of CD16 (Leu-11) and Leu-19 (NKH-1) antigen expression on human peripheral blood NK cells and cytotoxic $\mathrm{T}$ lymphocytes. J Immunol. (1986) 136:4480-6.

85. Papewalis C, Jacobs B, Wuttke M, Ullrich E, Baehring T, Fenk R, et al. IFNalpha skews monocytes into CD56+-expressing dendritic cells with potent functional activities in vitro and in vivo. J Immunol. (2008) 180:1462-70. doi: 10.4049/jimmunol.180.3.1462

86. Harada H, Kawano MM, Huang N, Harada Y, Iwato K, Tanabe $\mathrm{O}$, et al. Phenotypic difference of normal plasma cells from mature myeloma cells. Blood. (1993) 81:2658-63. doi: 10.1182/blood.V81.10.2658.bloodjournal81102658

87. van Camp B, Durie BG, Spier C, De Waele M, van Riet I, Vela E, et al. Plasma cells in multiple myeloma express a natural killer cellassociated antigen: CD56 (NKH-1; Leu-19). Blood. (1990) 76:377-82. doi: 10.1182/blood.V76.2.377.bloodjournal762377

88. Van Riet I, De Waele M, Remels L, Lacor P, Schots R, Van Camp B. Expression of cytoadhesion molecules (CD56, CD54, CD18 and CD29) by myeloma plasma cells. Br J Haematol. (1991) 79:421-7. doi: 10.1111/j.1365-2141.1991.tb08050.x

89. Ely SA, Knowles DM. Expression of CD56/neural cell adhesion molecule correlates with the presence of lytic bone lesions in multiple myeloma and distinguishes myeloma from monoclonal gammopathy of undetermined significance and lymphomas with plasmacytoid differentiation. Am J Pathol. (2002) 160:1293-9. doi: 10.1016/S0002-9440(10)62556-4

90. Kraj M, Sokołowska U, Kopeć-Szlezak J, Pogłód R, Kruk B, Wozniak J, et al. Clinicopathological correlates of plasma cell CD56 (NCAM) expression in multiple myeloma. Leuk Lymphoma. (2008) 49:298-305. doi: $10.1080 / 10428190701760532$

91. Pellat-Deceunynck C, Barillé S, Jego G, Puthier D, Robillard N, Pineau $\mathrm{D}$, et al. The absence of CD56 (NCAM) on malignant plasma cells is a hallmark of plasma cell leukemia and of a special subset of multiple myeloma. Leukemia. (1998) 12:1977-82. doi: 10.1038/sj.leu.2401211

92. Sahara N, Takeshita A, Shigeno K, Fujisawa S, Takeshita K, Naito $\mathrm{K}$, et al. Clinicopathological and prognostic characteristics of CD56-negative multiple myeloma. $\mathrm{Br} J$ Haematol. (2002)117:882-5. doi: 10.1046/j.1365-2141.2002.03513.x

93. Jelinek T, Hajek R. Monoclonal antibodies - a new era in the treatment of multiple myeloma. Blood Rev. (2016) 30:101-10. doi: 10.1016/j.blre.2015.08.004

94. Gil-Yarom N, Radomir L, Sever L, Kramer MP, Lewinsky H, Bornstein C, et al. CD74 is a novel transcription regulator. Proc Natl Acad Sci USA. (2017) 114:562-7. doi: 10.1073/pnas.1612195114

95. Burton JD, Ely S, Reddy PK, Stein R, Gold DV, Cardillo TM, et al. CD74 is expressed by multiple myeloma and is a promising target for therapy. Clin Cancer Res. (2004) 10:6606-11. doi: 10.1158/1078-0432.CCR04-0182

96. Liszewski MK, Post TW, Atkinson JP. Membrane cofactor protein (MCP or CD46): newest member of the regulators of complement activation gene cluster. Annu Rev Immunol. (1991) 9:431-55. doi: 10.1146/annurev.iy.09.040191.002243

97. Ong HT, Timm MM, Greipp PR, Witzig TE, Dispenzieri A, Russell SJ, et al. Oncolytic measles virus targets high CD46 expression on multiple myeloma cells. Exp Hematol. (2006) 34:713-20. doi: 10.1016/j.exphem.2006.03.002

98. Yamaizumi M, Mekada E, Uchida T, Okada Y. One molecule of diphtheria toxin fragment A introduced into a cell can kill the cell. Cell. (1978) 15:24550. doi: 10.1016/0092-8674(78)90099-5

99. Eiklid K, Olsnes S, Pihl A. Entry of lethal doses of abrin, ricin and modeccin into the cytosol of HeLa cells. Exp Cell Res. (1980) 126:321-6. doi: 10.1016/0014-4827(80)90270-0

100. Kim J-S, Jun S-Y, Kim Y-S. Critical issues in the development of immunotoxins for anticancer therapy. J Pharm Sci. (2020) 109:104-15. doi: 10.1016/j.xphs.2019.10.037

101. Walsh MJ, Dodd JE, Hautbergue GM. Ribosome-inactivating proteins. Virulence. (2013) 4:774-84. doi: 10.4161/viru.26399

102. Leshem Y, Pastan I. Pseudomonas exotoxin immunotoxins and anti-tumor immunity: from observations at the patient's bedside to evaluation in preclinical models. Toxins. (2019) 11:20. doi: 10.3390/toxins 11010020

103. Mazor R, Onda M, Pastan I. Immunogenicity of therapeutic recombinant immunotoxins. Immunol Rev. (2016) 270:152-64. doi: 10.1111/imr.12390 
104. Mazor R, Eberle JA, Hu X, Vassall AN, Onda M, Beers R, et al. Recombinant immunotoxin for cancer treatment with low immunogenicity by identification and silencing of human T-cell epitopes. Proc Natl Acad Sci USA. (2014) 111:8571-6. doi: 10.1073/pnas.1405153111

105. Mazor R, King EM, Pastan I. Strategies to reduce the immunogenicity of recombinant immunotoxins. Am J Pathol. (2018) 188:1736-43. doi: 10.1016/j.ajpath.2018.04.016

106. Pastan I, Hassan R, FitzGerald DJ, Kreitman RJ. Immunotoxin therapy of cancer. Nat Rev Cancer. (2006) 6:559-65. doi: 10.1038/nrc1891

107. Wayne AS, FitzGerald DJ, Kreitman RJ, Pastan I. Immunotoxins for leukemia. Blood. (2014) 123:2470-7. doi: 10.1182/blood-2014-01-492256

108. Kreitman RJ, Dearden C, Zinzani PL, Delgado J, Karlin L, Robak T, et al. Moxetumomab pasudotox in relapsed/refractory hairy cell leukemia. Leukemia. (2018) 32:1768-77. doi: 10.1038/s41375-018-0210-1

109. Willert EK, Robinson GL, Higgins JP, Liu J, Lee J, Syed S, et al. Abstract 2384: TAK-169, an exceptionally potent CD38 targeted engineered toxin body, as a novel direct cell kill approach for the treatment of multiple myeloma [abstract]. In: Proceedings of the American Association for Cancer Research Annual Meeting, Vol. 79. Atlanta, GA; Philadelphia, PA: AACR; Cancer Research (2019).

110. Kumar SK, Cornell RF, Landgren O, Ailawadhi S, Higgins JP, Willert EK, et al. Abstract 1867: A phase 1 first-in-human study of the anti-CD38 dimeric fusion protein TAK-169 for the treatment of patients (pts) with relapsed or refractory multiple myeloma (RRMM) who are proteasome inhibitor (PI)- and immunomodulatory drug (IMiD)-refractory, including Pts relapsed/refractory (R/R) or naïve to daratumumab (dara). In: 61st Annual Meeting and Exposition (December 7-10, 2019). Orlando, FL: American Society of Hematology (2019). p. 1867. doi: 10.1182/blood-2019125629

111. Deaglio S, Mehta K, Malavasi F. Human CD38: a (r)evolutionary story of enzymes and receptors. Leuk Res. (2001) 25:1-12. doi: 10.1016/S0145-2126(00)00093-X

112. Lee HC. Structure and enzymatic functions of human CD38. Mol Med. (2006) 12:317-23. doi: 10.2119/2006-00086.Lee

113. Lin P, Owens R, Tricot G, Wilson CS. Flow cytometric immunophenotypic analysis of 306 cases of multiple myeloma. Am J Clin Pathol. (2004) 121:4828. doi: 10.1309/74R4TB90BUWH27JX

114. Krejcik J, Casneuf T, Nijhof IS, Verbist B, Bald J, Plesner T, et al. Daratumumab depletes CD38+ immune regulatory cells, promotes T-cell expansion, and skews T-cell repertoire in multiple myeloma. Blood. (2016) 128:384-94. doi: 10.1182/blood-2015-12-687749

115. Rajagopalan S, Robinson GL, Brieschke B, Erdman J, Neill J, Higgins JP, et al. Abstract 595: Next-generation engineered toxin bodies: CD38, PD-L1 and HER2 targeted ETBs [abstract]. In: Proceedings of the 107th Annual Meeting of the American Association for Cancer Research, Vol. 76. New Orleans, LA; Philadelphia, PA: AACR; Cancer Research (2016).

116. Robinson GL, Rajagopalan S, Brieschke B, Neill J, Erdman J, Flores R, et al. Abstract 2659: MT-4019: a de-immunized engineered toxin body targeting CD38 for multiple myeloma. In: Proceedings of the American Association for Cancer Research Annual Meeting. Washington, DC; Philadelphia, PA: Cancer Research; American Association for Cancer Research (2017). p. 2659. doi: 10.1158/1538-7445.AM2017-2659

117. Li T, Qi S, Unger M, Hou YN, Deng QW, Liu J, et al. Immunotargeting the multifunctional CD38 using nanobody. Sci Rep. (2016) 6:27055. doi: $10.1038 /$ srep27055

118. Nijhof IS, Groen RWJ, Lokhorst HM, van Kessel B, Bloem AC, van Velzen J, et al. Upregulation of CD38 expression on multiple myeloma cells by alltrans retinoic acid improves the efficacy of daratumumab. Leukemia. (2015) 29:2039-49. doi: 10.1038/leu.2015.123

119. Bolognesi A, Polito L, Farini V, Bortolotti M, Tazzari PL, Ratta M, et al. CD38 as a target of IB4 mAb carrying saporin-S6: design of an immunotoxin for ex vivo depletion of hematological CD38+ neoplasia. J Biol Regul Homeost Agents. (2005) 19:145-52.

120. Flavell DJ, Cooper S, Okayama K, Emery L, Flavell SU. Comparison of the performance of anti-CD7 and anti-CD38 bispecific antibodies and immunotoxins for the delivery of saporin to a human T-cell acute lymphoblastic leukemia cell line. Hematol Oncol. (1995) 13:185-200. doi: 10.1002/hon.2900130403
121. Goldmacher VS, Bourret LA, Levine BA, Rasmussen RA, Pourshadi M, Lambert JM, et al. Anti-CD38-blocked ricin: an immunotoxin for the treatment of multiple myeloma. Blood. (1994) 84:3017-25. doi: 10.1182/blood.V84.9.3017.bloodjournal8493017

122. Daniels TR, Ng PP, Delgado T, Lynch MR, Schiller G, Helguera G, et al. Conjugation of an anti transferrin receptor IgG3-avidin fusion protein with biotinylated saporin results in significant enhancement of its cytotoxicity against malignant hematopoietic cells. Mol Cancer Ther. (2007) 6:2995-3008. doi: 10.1158/1535-7163.MCT-07-0330

123. Chang C-H, Sapra P, Vanama SS, Hansen HJ, Horak ID, Goldenberg DM. Effective therapy of human lymphoma xenografts with a novel recombinant ribonuclease/anti-CD74 humanized IgG4 antibody immunotoxin. Blood. (2005) 106:4308-14. doi: 10.1182/blood-2005-03-1033

124. Vooijs WC, Post J, Wijdenes J, Schuurman HJ, Bolognesi A, Polito L, et al. Efficacy and toxicity of plasma-cell-reactive monoclonal antibodies B-B2 and B-B4 and their immunotoxins. Cancer Immunol Immunother. (1996) 42:319-28. doi: 10.1007/s002620050289

125. Bera TK, Abe Y, Ise T, Oberle A, Gallardo D, Liu X-F, et al. Recombinant immunotoxins targeting B-cell maturation antigen are cytotoxic to myeloma cell lines and myeloma cells from patients. Leukemia. (2018) 32:569-72. doi: 10.1038/leu.2017.315

126. Shancer Z, Williams M, Igelman A, Nagata S, Ise T, Pastan I, et al. Preclinical development of anti-BCMA immunotoxins targeting multiple myeloma. Antib Ther. (2018) 1:19-25. doi: 10.1093/abt/tby004

127. Shancer Z, Liu X, Nagata S, Zhou Q, Bera TK, Pastan I. AntiBCMA immunotoxins produce durable complete remissions in two mouse myeloma models. Proc Natl Acad Sci USA. (2019) 116:4592-8. doi: $10.1073 /$ pnas.1821733116

128. Staudinger M, Glorius P, Burger R, Kellner C, Klausz K, Günther A, et al. The novel immunotoxin HM1.24-ETA' induces apoptosis in multiple myeloma cells. Blood Cancer J. (2014) 4:e219. doi: 10.1038/bcj.2014.38

129. Lyu M-A, Cheung LH, Hittelman WN, Marks JW, Aguiar RCT, Rosenblum MG. The rGel/BLyS fusion toxin specifically targets malignant B cells expressing the BLyS receptors BAFF-R, TACI, and BCMA. Mol Cancer Ther. (2007) 6:460-70. doi: 10.1158/1535-7163.MCT-06-0254

130. Weldon JE, Xiang L, Chertov O, Margulies I, Kreitman RJ, FitzGerald DJ, et al. A protease-resistant immunotoxin against CD22 with greatly increased activity against CLL and diminished animal toxicity. Blood. (2009) 113:3792800. doi: 10.1182/blood-2008-08-173195

131. Kaplan G, Lee F, Onda M, Kolyvas E, Bhardwaj G, Baker D, et al. Protection of the furin cleavage site in low-toxicity immunotoxins based on pseudomonas exotoxin A. Toxins. (2016) 8:217. doi: 10.3390/toxins8080217

132. Neil SJD, Zang T, Bieniasz PD. Tetherin inhibits retrovirus release and is antagonized by HIV-1 Vpu. Nature. (2008) 451:425-30. doi: 10.1038 /nature 06553

133. Jouvenet N, Neil SJD, Zhadina M, Zang T, Kratovac Z, Lee Y, et al. Broadspectrum inhibition of retroviral and filoviral particle release by tetherin. $J$ Virol. (2009) 83:1837-44. doi: 10.1128/JVI.02211-08

134. Cocka LJ, Bates P. Identification of alternatively translated tetherin isoforms with differing antiviral and signaling activities. PLoS Pathog. (2012) 8:e1002931. doi: 10.1371/journal.ppat.1002931

135. Tokarev A, Suarez M, Kwan W, Fitzpatrick K, Singh R, Guatelli J. Stimulation of NF- $\mathrm{B}$ activity by the HIV restriction factor BST2. J Virol. (2013) 87:2046-57. doi: 10.1128/JVI.02272-12

136. Goto T, Kennel SJ, Abe M, Takishita M, Kosaka M, Solomon A, et al. A novel membrane antigen selectively expressed on terminally differentiated human B cells. Blood. (1994) 84:1922-30. doi: 10.1182/blood.V84.6.1922.bloodjournal8461922

137. Ishikawa J, Kaisho T, Tomizawa H, Lee BO, Kobune $\mathrm{Y}$, Inazawa J, et al. Molecular cloning and chromosomal mapping of a bone marrow stromal cell surface gene, BST2, that may be involved in pre-B-cell growth. Genomics. (1995) 26:527-34. doi: 10.1016/0888-7543(95)80171-H

138. Erikson E, Adam T, Schmidt S, Lehmann-Koch J, Over B, Goffinet C, et al. In vivo expression profile of the antiviral restriction factor and tumor-targeting antigen CD317/BST-2/HM1.24/tetherin in humans. Proc Natl Acad Sci USA. (2011) 108:13688-93. doi: 10.1073/pnas.1101684108

139. Ozaki S, Kosaka M, Wakatsuki S, Abe M, Koishihara Y, Matsumoto T. Immunotherapy of multiple myeloma with a monoclonal antibody directed 
against a plasma cell-specific antigen, HM1.24. Blood. (1997) 90:3179-86. doi: 10.1182/blood.V90.8.3179

140. Ohtomo T, Sugamata Y, Ozaki Y, Ono K, Yoshimura Y, Kawai S, et al. Molecular cloning and characterization of a surface antigen preferentially overexpressed on multiple myeloma cells. Biochem Biophys Res Commun. (1999) 258:583-91. doi: 10.1006/bbrc.1999.0683

141. Cai D, Cao J, Li Z, Zheng X, Yao Y, Li W, et al. Up-regulation of bone marrow stromal protein 2 (BST2) in breast cancer with bone metastasis. BMC Cancer. (2009) 9:102. doi: 10.1186/1471-2407-9-102

142. Wang W, Nishioka Y, Ozaki S, Jalili A, Abe S, Kakiuchi S, et al. HM1.24 (CD317) is a novel target against lung cancer for immunotherapy using anti-HM1.24 antibody. Cancer Immunol Immunother. (2009) 58:967-76. doi: 10.1007/s00262-008-0612-4

143. Pasche $\mathrm{N}$, Neri D. Immunocytokines: a novel class of potent armed antibodies. Drug Discov Today. (2012) 17:583-90. doi: 10.1016/j.drudis.2012.01.007

144. Bootz F, Neri D. Immunocytokines: a novel class of products for the treatment of chronic inflammation and autoimmune conditions. Drug Discov Today. (2016) 21:180-9. doi: 10.1016/j.drudis.2015.10.012

145. Baldo BA. Side effects of cytokines approved for therapy. Drug Saf. (2014) 37:921-43. doi: 10.1007/s40264-014-0226-Z

146. Gillies SD, Lo K-M, Burger C, Lan Y, Dahl T, Wong W-K. Improved circulating half-life and efficacy of an antibody-interleukin 2 immunocytokine based on reduced intracellular proteolysis. Clin Cancer Res. (2002) 8:210-6.

147. Rossi EA, Rossi DL, Cardillo TM, Stein R, Goldenberg DM, Chang C-H. Preclinical studies on targeted delivery of multiple IFN $\alpha 2 b$ to HLA-DR in diverse hematologic cancers. Blood. (2011) 118:1877-84. doi: 10.1182/blood-2011-03-343145

148. Grandér D, Einhorn S. Interferon and malignant disease-how does it work and why doesn't it always? Acta Oncol. (1998) 37:331-8. doi: $10.1080 / 028418698430548$

149. Gazitt Y. TRAIL is a potent inducer of apoptosis in myeloma cells derived from multiple myeloma patients and is not cytotoxic to hematopoietic stem cells. Leukemia. (1999) 13:1817-24. doi: 10.1038/sj.leu.2401501

150. Labrinidis A, Diamond P, Martin S, Hay S, Liapis V, Zinonos I, et al. Apo2L/TRAIL inhibits tumor growth and bone destruction in a murine model of multiple myeloma. Clin Cancer Res. (2009) 15:1998-2009. doi: 10.1158/1078-0432.CCR-08-2444

151. Mitsiades CS, Treon SP, Mitsiades N, Shima Y, Richardson P, Schlossman $\mathrm{R}$, et al. TRAIL/Apo2L ligand selectively induces apoptosis and overcomes drug resistance in multiple myeloma: therapeutic applications. Blood. (2001) 98:795-804. doi: 10.1182/blood.V98.3.795

152. Otsuki T, Yamada O, Sakaguchi H, Tomokuni A, Wada H, Yawata Y, et al. Human myeloma cell apoptosis induced by interferon-alpha. Br J Haematol. (1998) 103:518-29. doi: 10.1046/j.1365-2141.1998.01000.x

153. Hervas-Stubbs S, Perez-Gracia JL, Rouzaut A, Sanmamed MF, Bon AL, Melero I. Direct effects of type I interferons on cells of the immune system. Clin Cancer Res. (2011) 17:2619-27. doi: 10.1158/1078-0432.CCR-10-1114

154. Pogue SL, Preston BT, Stalder J, Bebbington CR, Cardarelli PM. The receptor for type I IFNs is highly expressed on peripheral blood B cells and monocytes and mediates a distinct profile of differentiation and activation of these cells. $J$ Interferon Cytokine Res. (2004) 24:131-9. doi: 10.1089/107999004322813372

155. Slaton JW, Perrotte P, Inoue K, Dinney CPN, Fidler IJ. Interferon- $\alpha-$ mediated down-regulation of angiogenesis-related genes and therapy of bladder cancer are dependent on optimization of biological dose and schedule. Clin Cancer Res. (1999) 5:2726-34.

156. Von Marschall Z, Scholz A, Cramer T, Schäfer G, Schirner M, Öberg K, et al. Effects of interferon alpha on vascular endothelial growth factor gene transcription and tumor angiogenesis. J Natl Cancer Inst. (2003) 95:437-48. doi: 10.1093/jnci/95.6.437

157. Myeloma Trialists' Collaborative Group. Interferon as therapy for multiple myeloma: an individual patient data overview of 24 randomized trials and 4012 patients. Br J Haematol. (2001) 113:1020-34. doi: 10.1046/j.1365-2141.2001.02857.x

158. WislØff F, Hjorth M, Kaasa S, Westin J. Effect of interferon on the health-related quality of life of multiple myeloma patients: results of a Nordic randomized trial comparing melphalan-prednisone to melphalan-prednisone $+\alpha$-interferon. Br J Haematol. (1996) 94:324-32. doi: 10.1046/j.1365-2141.1996.d01-1802.x

159. Schaar CG, Kluin-Nelemans HC, Te Marvelde C, le Cessie S, Breed WP, Fibbe $\mathrm{WE}$, et al. Interferon-alpha as maintenance therapy in patients with multiple myeloma. Ann Oncol. (2005) 16:634-9. doi: 10.1093/annonc/mdi125

160. Rossi EA, Rossi DL, Stein R, Goldenberg DM, Chang C-H. A bispecific antibody-IFN $\alpha 2 \mathrm{~b}$ immunocytokine targeting CD20 and HLA-DR is highly toxic to human lymphoma and multiple myeloma cells. Cancer Res. (2010) 70:7600-9. doi: 10.1158/0008-5472.CAN-10-2126

161. Yoo EM, Trinh KR, Tran D, Vasuthasawat A, Zhang J, Hoang B, et al. Anti-CD138-targeted interferon is a potent therapeutic against multiple myeloma. I Interferon Cytokine Res. (2015) 35:281-91. doi: 10.1089/jir.20 14.0125

162. Pogue SL, Taura T, Bi M, Yun Y, Sho A, Mikesell G, et al. Targeting attenuated interferon- $\alpha$ to myeloma cells with a CD38 antibody induces potent tumor regression with reduced off-target activity. PLOS ONE. (2016) 11:0162472. doi: 10.1371/journal.pone.0162472

163. Vasuthasawat A, Yoo EM, Trinh KR, Lichtenstein A, Timmerman JM, Morrison SL. Targeted immunotherapy using anti-CD138interferon $\alpha$ fusion proteins and bortezomib results in synergistic protection against multiple myeloma. MAbs. (2016) 8:1386-97. doi: 10.1080/19420862.2016.1207030

164. Pogue S, Bi M, Armanini M, Fatholahi M, Taura T, Valencia M, et al. Attenuated interferon- $\alpha$ targeted to CD38 expressing multiple myeloma tumor cells induces robust and durable anti-tumor responses through direct anti-proliferative activity in addition to indirect recruitment and activation of M1 macrophages. In: 59th Annual Meeting and Exposition. December 9-12 Atlanta, GA: American Society of Hematology (2017) 130(Suppl. 1):3112.

165. de Luca R, Kachel P, Kropivsek K, Manz MG, Neri D. A novel dual-cytokine antibody fusion protein for the treatment of CD38-positive malignancies. Protein Eng Des Sel. (2018) 31:173-9. doi: 10.1093/protein/gzy015

166. Menssen HD, Harnack U, Erben U, Neri D, Hirsch B, Dürkop H. Antibodybased delivery of tumor necrosis factor (L19-TNF $\alpha)$ and interleukin-2 (L19-IL2) to tumor-associated blood vessels has potent immunological and anticancer activity in the syngeneic J558L BALB/c myeloma model. J Cancer Res Clin Oncol. (2018) 144:499-507. doi: 10.1007/s00432-01 7-2564-6

167. Jiang T, Zhou C, Ren S. Role of IL-2 in cancer immunotherapy. Oncoimmunology. (2016) 5:e1163462. doi: 10.1080/2162402X.2016.1163462

168. Mortara L, Balza E, Bruno A, Poggi A, Orecchia P, Carnemolla B. Anticancer therapies employing IL-2 cytokine tumor targeting: contribution of innate, adaptive and immunosuppressive cells in the anti-tumor efficacy. Front Immunol. (2018) 9:2905. doi: 10.3389/fimmu.2018.02905

169. Shaffer AL, Emre NCT, Lamy L, Ngo VN, Wright G, Xiao W, et al. IRF4 addiction in multiple myeloma. Nature. (2008) 454:226-31. doi: 10.1038/nature07064

170. Agnarelli A, Chevassut T, Mancini EJ. IRF4 in multiple myelomaBiology, disease and therapeutic target. Leuk Res. (2018) 72:52-8. doi: 10.1016/j.leukres.2018.07.025

171. Kraeber-Bodéré F, Bodet-Milin C, Rousseau C, Eugène T, Pallardy A, Frampas E, et al. Radioimmunoconjugates for the treatment of cancer. Semin Oncol. (2014) 41:613-22. doi: 10.1053/j.seminoncol.2014.07.004

172. Larson SM, Carrasquillo JA, Cheung N-KV, Press O. Radioimmunotherapy of human tumours. Nat Rev Cancer. (2015) 15:347-60. doi: 10.1038/nr c3925

173. Ghai A, Maji D, Cho N, Chanswangphuwana C, Rettig M, Shen $\mathrm{D}$, et al. Preclinical development of CD38-Targeted [89Zr]Zr-DFOdaratumumab for imaging multiple myeloma. J Nucl Med. (2018) 59:216-22. doi: 10.2967/jnumed.117.196063

174. Caserta E, Chea J, Minnix M, Poku EK, Viola D, Vonderfecht S, et al. Copper 64-labeled daratumumab as a PET/CT imaging tracer for multiple myeloma. Blood. (2018) 131:741-5. doi: 10.1182/blood-2017-09-807263

175. Ulaner GA, Sobol NB, O’Donoghue JA, Kirov AS, Riedl CC, Min $\mathrm{R}$, et al. CD38-targeted immuno-PET of multiple myeloma: from xenograft models to first-in-human imaging. Radiology. (2020) 2020:192621. doi: 10.1148/radiol.2020192621

176. Green DJ, Orgun NN, Jones JC, Hylarides MD, Pagel JM, Hamlin DK, et al. A preclinical model of CD38-pretargeted radioimmunotherapy 
for plasma cell malignancies. Cancer Res. (2014) 74:1179-89. doi: 10.1158/0008-5472.CAN-13-1589

177. Green DJ, O'Steen S, Lin Y, Comstock ML, Kenoyer AL, Hamlin DK, et al. CD38-bispecific antibody pretargeted radioimmunotherapy for multiple myeloma and other B-cell malignancies. Blood. (2018) 131:611-20. doi: 10.1182/blood-2017-09-807610

178. Mill WB, Griffith R. The role of radiation therapy in the management of plasma cell tumors. Cancer. (1980) 45:647-52.

179. Talamo G, Dimaio C, Abbi KKS, Pandey MK, Malysz J, Creer MH, et al. Current role of radiation therapy for multiple myeloma. Front Oncol. (2015) 5:40. doi: $10.3389 /$ fonc. 2015.00040

180. Jakubowiak A, Hari M, Al-Zoubi A, Kendall T, Khaled Y, Mineishi $\mathrm{S}$, et al. Targeted therapy against clonogenic myeloma cells with iodine I-131 Tositumomab (Bexxar ${ }^{\mathrm{TM}}$ ). Blood. (2007) 110:4796. doi: 10.1182/blood.V110.11.4796.4796

181. Lebovic D, Kaminski MS, Anderson TB, Detweiler-Short K, Griffith KA, Jobkar TL, et al. A phase II study of consolidation treatment with iodione131 Tositumomab (Bexxar ${ }^{\mathrm{TM}}$ ) in multiple myeloma (MM). Blood. (2012) 120:1854. doi: 10.1182/blood.V120.21.1854.1854

182. Gao L, Sprague KA, Nikpoor N, Klingemann HG, Miller KB, Comenzo R, et al. A phase II, safety and efficacy study of fixed dose radioimmunotherapy (Zevalin, yttrium-90 ibritumomab tiuxetan) for patients with incomplete response to chemotherapy prior to autologous stem cell transplant (ASCT) for multiple myeloma. Biol Blood Marrow Transplant. (2015) 21:S199. doi: 10.1016/j.bbmt.2014.11.304

183. Dispenzieri A, D’Souza A, Gertz MA, Laumann K, Wiseman G, Lacy MQ, et al. A phase 1 trial of 90Y-Zevalin radioimmunotherapy with autologous stem cell transplant for multiple myeloma. Bone Marrow Transplant. (2017) 52:1372-7. doi: 10.1038/bmt.2017.164

184. Levy MY, Cicic D, Bergonio G, Berger M. Trial in progress: phase I study of actinium-225 (225Ac)-Lintuzumab in patients with refractory multiple myeloma. Clin Lymphoma Myeloma Leuk. (2017) 17:S329-30. doi: 10.1016/j.clml.2017.07.141

185. Dawicki W, Allen KJH, Jiao R, Malo ME, Helal M, Berger MS, et al. Daratumumab-225Actinium conjugate demonstrates greatly enhanced antitumor activity against experimental multiple myeloma tumors. Oncoimmunology. (2019) 8:1607673. doi: 10.1080/2162402X.2019.160 7673

186. O'Steen S, Comstock ML, Orozco JJ, Hamlin DK, Wilbur DS, Jones JC, et al. The $\alpha$-emitter astatine-211 targeted to CD38 can eradicate multiple myeloma in a disseminated disease model. Blood. (2019) 134:1247-56. doi: 10.1182/blood.2019001250

187. Teiluf K, Seidl C, Blechert B, Gaertner FC, Gilbertz K-P, Fernandez V, et al. $\alpha$-Radioimmunotherapy with $213 \mathrm{Bi}$-anti-CD38 immunoconjugates is effective in a mouse model of human multiple myeloma. Oncotarget. (2014) 6:4692-703. doi: 10.18632/oncotarget.2986

188. Quelven I, Monteil J, Sage M, Saidi A, Mounier J, Bayout A, et al. $212 \mathrm{~Pb}$ Alpha-Radioimmunotherapy targeting CD38 in Multiple Myeloma: a preclinical study. J Nucl Med. (2019) doi: 10.2967/jnumed.119.239491. [Epub ahead of print].

189. Rousseau C, Ferrer L, Supiot S, Bardiès M, Davodeau F, Faivre-Chauvet A, et al. Dosimetry results suggest feasibility of radioimmunotherapy using antiCD138 (B-B4) antibody in multiple myeloma patients. Tumour Biol. (2012) 33:679-88. doi: 10.1007/s13277-012-0362-y

190. Couturier O, Faivre-Chauvet A, Filippovich IV, Thédrez P, Saï-Maurel C, Bardiès $\mathrm{M}$, et al. Validation of 213Bi-alpha radioimmunotherapy for multiple myeloma. Clin Cancer Res. (1999) 5(10 Suppl):3165s-70s.

191. Supiot S, Faivre-Chauvet A, Couturier O, Heymann MF, Robillard N, Kraeber-Bodéré F, et al. Comparison of the biologic effects of MA5 and B-B4 monoclonal antibody labeled with iodine-131 and bismuth-213 on multiple myeloma. Cancer. (2002) 94(4 Suppl.):1202-9. doi: 10.1002/cncr.10286

192. Chérel M, Gouard S, Gaschet J, Saï-Maurel C, Bruchertseifer F, Morgenstern A, et al. 213Bi radioimmunotherapy with an anti-mCD138 monoclonal antibody in a murine model of multiple myeloma. J Nucl Med. (2013) 54:1597-604. doi: 10.2967/jnumed.112.111997

193. Fichou N, Gouard S, Maurel C, Barbet J, Ferrer L, Morgenstern A, et al. Single-dose anti-CD138 radioimmunotherapy: bismuth-213 is more efficient than lutetium-177 for treatment of multiple myeloma in a preclinical model. Front Med. (2015) 2:76. doi: 10.3389/fmed.2015.00076

194. Baidoo KE, Yong K, Brechbiel MW. Molecular pathways: targeted a-particle radiation therapy. Clin Cancer Res. (2013) 19:530-7. doi: 10.1158/1078-0432.CCR-12-0298

195. Feinendegen LE, McClure JJ. Alpha-emitters for medical therapy: workshop of the united states department of energy: denver, Colorado, May 30-31, 1996. Radiation Res. (1997) 148:195-201. doi: 10.2307/3579579

196. Sahara N, Ohnishi K, Ono T, Sugimoto Y, Kobayashi M, Takeshita $\mathrm{K}$, et al. Clinicopathological and prognostic characteristics of CD33-positive multiple myeloma. Eur J Haematol. (2006) 77:14-8. doi: $10.1111 / j .1600-0609.2006 .00661 . x$

197. Shim H, Ha JH, Lee H, Sohn JY, Kim HJ, Eom H-S, et al. Expression of myeloid antigen in neoplastic plasma cells is related to adverse prognosis in patients with multiple myeloma. Biomed Res Int. (2014) 2014:893243. doi: $10.1155 / 2014 / 893243$

198. Oka S, Ono K, Nohgawa M. Clinical effects of CD33 and MPC-1 on the prognosis of multiple myeloma treated with bortezomib. Leukemia Lymphoma. (2019) 60:2152-7. doi: 10.1080/10428194.2019.1574003

199. Haymart M, Banerjee M, Stewart A, Koenig R, Birkmeyer J, Griggs J. Use of radioactive iodine for thyroid cancer. JAMA. (2011) 306:721-8. doi: 10.1001/jama.2011.1139

200. Miguel JFS, Gonzáalez M, Gascón A, Moro MJ, Hernáandez JM, Ortega F, et al. Immunophenotypic heterogeneity of multiple myeloma: influence on the biology and clinical course of the disease. Br J Haematol. (1991) 77:185-90. doi: 10.1111/j.1365-2141.1991. tb07975.x

201. Leo R, Boeker M, Peest D, Hein R, Bartl R, Gessner JE, et al. Multiparameter analyses of normal and malignant human plasma cells: CD38++, CD56+, CD54+, cIg+ is the common phenotype of myeloma cells. Ann Hematol. (1992) 64:132-9. doi: 10.1007/BF01697400

202. Robillard N, Avet-Loiseau H, Garand R, Moreau P, Pineau D, Rapp $\mathrm{M}-\mathrm{J}$, et al. CD20 is associated with a small mature plasma cell morphology and $\mathrm{t}(11 ; 14)$ in multiple myeloma. Blood. (2003) 102:1070-1. doi: 10.1182/blood-2002-11-3333

203. Food Drug Administration. GlaxoSmithKline LLC; Withdrawal of Approval of the Indication for Treatment of Patients With Relapsed or Refractory, Low Grade, Follicular, or Transformed CD20 Positive Non-Hodgkin's Lymphoma Who Have Not Received Prior Rituximab; BEXXAR. (2013). Available online at: https://www.federalregister.gov/documents/2013/10/23/201324840/glaxosmithkline-llc-withdrawal-of-approval-of-the-indication-fortreatment-of-patients-with-relapsed (cited December 27, 2019)

204. Walker LA. Radioactive Yttrium 90: a review of its properties, biological behavior, and clinical uses. Acta Radiologica Ther Phys Biol. (1964)2:302-14. doi: $10.1080 / 02841866409134063$

205. Alewine C, Xiang L, Yamori T, Niederfellner G, Bosslet K, Pastan I. Efficacy of RG7787, a next generation mesothelin-targeted immunotoxin, against triplenegative breast and gastric cancers. Mol Cancer Ther. (2014) 13:2653-61. doi: 10.1158/1535-7163.MCT-14-0132

206. Berdeja J. Updated results from an ongoing phase 1 clinical study of bb21217 anti-Bcma CAR T cell therapy. In: 61st Annual Meeting and Exposition. Orlando, FL: American Society of Hematology (2019). doi: 10.1182/blood-2019-126660

207. Haynes L, Maue AC. Effects of aging on T cell function. Curr Opin Immunol. (2009) 21:414-7. doi: 10.1016/j.coi.2009.05.009

208. Rosko A, Hofmeister C, Benson D, Efebera Y, Huang Y, Gillahan J, et al. Autologous hematopoietic stem cell transplant induces the molecular aging of T-cells in multiple myeloma. Bone Marrow Transplant. (2015) 50:1379-81. doi: 10.1038/bmt.2015.143

209. Suen H, Brown R, Yang S, Weatherburn C, Ho PJ, Woodland N, et al. Multiple myeloma causes clonal T-cell immunosenescence: identification of potential novel targets for promoting tumour immunity and implications for checkpoint blockade. Leukemia. (2016) 30:1716-24. doi: 10.1038/leu.2016.84

210. Wood WA, Krishnamurthy J, Mitin N, Torrice C, Parker JS, Snavely AC, et al. Chemotherapy and stem cell transplantation increase p16INK4a expression, a biomarker of T-cell aging. EBioMedicine. (2016) 11:227-38. doi: 10.1016/j.ebiom.2016.08.029 
211. Zelle-Rieser C, Thangavadivel S, Biedermann R, Brunner A, Stoitzner P, Willenbacher E, et al. $\mathrm{T}$ cells in multiple myeloma display features of exhaustion and senescence at the tumor site. J Hematol Oncol. (2016) 9:116. doi: 10.1186/s13045-016-0345-3

212. Kasakovski D, Xu L, Li Y. T cell senescence and CAR-T cell exhaustion in hematological malignancies. J Hematol Oncol. (2018) 11:91. doi: 10.1186/s13045-018-0629-x

213. Nijhof IS, Casneuf T, van Velzen J, van Kessel B, Axel AE, Syed K, et al. CD38 expression and complement inhibitors affect response and resistance to daratumumab therapy in myeloma. Blood. (2016) 128:959-70. doi: 10.1182/blood-2016-03-703439

214. Lee L, Draper B, Chaplin N, Philip B, Chin M, Galas-Filipowicz D, et al. An APRIL-based chimeric antigen receptor for dual targeting of BCMA and TACI in multiple myeloma. Blood. (2018) 131:746-58. doi: 10.1182/blood-2017-05-781351

215. Smith EL, Harrington K, Staehr M, Masakayan R, Jones J, Long TJ, et al. GPRC5D is a target for the immunotherapy of multiple myeloma with rationally designed CAR T cells. Sci Transl Med. (2019) 11:aau7746. doi: 10.1126/scitranslmed.aau7746

216. Cohen AD, Garfall AL, Stadtmauer EA, Melenhorst JJ, Lacey SF, Lancaster $\mathrm{E}$, et al. B cell maturation antigen-specific CAR T cells are clinically active in multiple myeloma. J Clin Invest. (2019) 129:2210-21. doi: 10.1172/JCI126397

217. Verkleij C, Broekmans M, Duin M van, Frerichs K, Kuiper R, Kaiser M, et al. Preclinical evaluation of the new GPRC5DxCD3 (JNJ-7564) bispecific antibody for the treatment of multiple myeloma. Clin Lymphoma Myeloma Leukemia. (2019)19:e122-3. doi: 10.1016/j.clml.2019.09.202

218. Frerichs KA, Broekmans MEC, Marin Soto JA, van Kessel B, Heymans MW, Holthof LC, et al. Preclinical activity of JNJ-7957, a novel $\mathrm{BCMA} \times \mathrm{CD} 3$ bispecific antibody for the treatment of multiple myeloma, is potentiated by Daratumumab. Clin Cancer Res. (2020) 26:2203-15. doi: 10.1158/1078-0432.CCR-19-2299

219. Ali SA, Shi V, Maric I, Wang M, Stroncek DF, Rose JJ, et al. T cells expressing an anti-B-cell maturation antigen chimeric antigen receptor cause remissions of multiple myeloma. Blood. (2016) 128:1688-700. doi: 10.1182/blood-2016-04-711903

220. Brudno JN, Maric I, Hartman SD, Rose JJ, Wang M, Lam N, et al. T cells genetically modified to express an anti-B-Cell maturation antigen chimeric antigen receptor cause remissions of poor-prognosis relapsed multiple myeloma. J Clin Oncol. (2018) 36:2267-80. doi: 10.1200/JCO.2018.77. 8084

221. McGrath MS, Rosenblum MG, Philips MR, Scheinberg DA. Immunotoxin resistance in multidrug resistant cells. Cancer Res. (2003) 63:72-9.
222. García-Alonso S, Ocaña A, Pandiella A. Resistance to antibody-drug conjugates. Cancer Res. (2018) 78:2159-65. doi: 10.1158/0008-5472.CAN-17-3671

223. Chen RW, Chen L, Herrera AF, Mei M, McBride K, Abary R, et al. Phase 1 study of mdrl inhibitor plus brentuximab vedotin in relapsed/refractory hodgkin lymphoma. Blood. (2018) 132(Suppl. 1):1636. doi: 10.1182/blood-2018-99-110403

224. Liu-Kreyche P, Shen H, Marino AM, Iyer RA, Humphreys WG, Lai Y. Lysosomal P-gp-MDR1 Confers drug resistance of brentuximab vedotin and its cytotoxic payload monomethyl auristatin E in tumor cells. Front Pharmacol. (2019) 10:749. doi: 10.3389/fphar.2019.00749

225. Chen R, Herrera AF, Hou J, Chen L, Wu J, Guo Y, et al. Inhibition of MDR1 overcomes resistance to Brentuximab vedotin in hodgkin lymphoma. Clin Cancer Res. (2020) 26:1034-44. doi: 10.1158/1078-0432.CCR-19-1768

226. García-Guerrero E, Gogishvili T, Danhof S, Schreder M, Pallaud C, PérezSimón JA, et al. Panobinostat induces CD38 upregulation and augments the antimyeloma efficacy of daratumumab. Blood. (2017) 129:3386-8. doi: 10.1182/blood-2017-03-770776

227. Choudhry P, Mariano MC, Geng H, Martin TG, Wolf JL, Wong SW, et al. DNA methyltransferase inhibitors upregulate CD38 protein expression and enhance daratumumab efficacy in multiple myeloma. Leukemia. (2020) 34:938-41. doi: 10.1038/s41375-019-0587-5

Conflict of Interest: SZ has received research support from Celgene, Janssen Pharmaceuticals and Takeda; and serves in advisory boards for Celgene, Janssen Pharmaceuticals, Takeda, Amgen, and Sanofi. TM has received research support from Janssen Pharmaceuticals, Genmab, Takeda, Onkimmune, and Gadeta. ND has received research support from Janssen Pharmaceuticals, AMGEN, Celgene, Novartis, and BMS; and serves in advisory boards for Janssen Pharmaceuticals, AMGEN, Celgene, BMS, Takeda, Roche, Novartis, Bayer, and Servier.

The remaining authors declare that the research was conducted in the absence of any commercial or financial relationships that could be construed as a potential conflict of interest.

Copyright (c) 2020 Bruins, Zweegman, Mutis and van de Donk. This is an open-access article distributed under the terms of the Creative Commons Attribution License (CC $B Y)$. The use, distribution or reproduction in other forums is permitted, provided the original author(s) and the copyright owner(s) are credited and that the original publication in this journal is cited, in accordance with accepted academic practice. No use, distribution or reproduction is permitted which does not comply with these terms. 